Teologia i Moralność, volumen 12(2017), numer 1(21)

doi: 10.14746/tim.2017.21.1.12

JERZY BERNACIAK

Katolicki Uniwersytet Lublelski

Wydział Teologii

\title{
Rola milości w przeżywaniu cierpienia i śmierci
}

Cierpienie i śmierć to istotne wymiary bytowania człowieka. Dlatego nikt, niezależnie od tego w jakim czasie żyje, nie może przejść obok nich obojętnie. Przedstawiciele różnych dyscyplin nauki pragną dopomóc człowiekowi w przyjęciu i przeżywaniu tych dwóch sytuacji egzystencjalnych ${ }^{1}$. W tym celu wciąż doskonali się sprzęt medyczny, modernizuje i udoskonala warunki szpitalne, jak również produkuje coraz bardziej różnorodne środki lecznicze, lecz mają one wpływ zasadniczo na fizyczno-chemiczną strukturę człowieka. Jednak z uwagi na to, że jest on bytem cielesno-duchowym, a w życiu duchowym najbardziej istotna jest potrzeba miłości, ma sens postawienie pytania: Jaka jest rola miłości w przyjęciu i przeżywaniu cierpienia oraz śmierci?

\section{Religijno-naturalna zdolność i potrzeba miłości jako fundament przeżywania cierpienia}

Za jedną z najbardziej istotnych przesłanek, na podstawie której podjęto próbę dania jednej z możliwych odpowiedzi na postawione pytanie, przyjęto przekonanie o naturalnej zdolności i potrzebie miłości. Biorąc ją pod uwagę jako punkt wyjścia, podkreślono też zdolność do przyjęcia i przeżywania cierpienia. Za jedną z konkluzji zgłębiania kwestii wpływu miłości na przeżywanie cierpienia i śmierci uznano pewną współzależność zdolności do przyjęcia i przeżywania tych dwóch stanów. W tym sensie zdolność przyjęcia oraz przeżywania cierpienia na fundamencie miłości i zgoda na nie potraktowana

${ }^{1}$ Por. A. Nowak, Do czytelnika, w: Cierpienie i śmierć, red. tenże, Homo Meditans, t. XIII, Lublin 1992, s. 7. 
została jako forma przeżywania miłości: „Wydaje się, że kto nie chce w życiu cierpieć, ten nie powinien miłować. Im ktoś bardziej zdolny jest do miłości, tym więcej cierpi"”. Przykładem realizacji tak rozumianej miłości jest przede wszystkim Jezus Chrystus, który jest równocześnie źródłem i dawcą zarówno miłości, jak i zdolności do przyjęcia i przeżywania cierpienia: „Chrystus jest Miłością, Miłością Nieskończoną i dlatego cierpiał od Ogrojca aż po Golgotę bezgranicznie, jak żaden człowiek"3.

Religijny aspekt wpływu miłości, nie tylko na przeżywanie cierpienia, ale i na jego pochodzenie, zgłębia Franciszek Drączkowski. Rozważania te opiera na nauce ojców Kościoła, powołując się m.in. na św. Augustyna. Na podstawie jego doktryny wyraża pogląd, że Bóg celowo dopuszcza na człowieka utrapienia, by go doprowadzić do siebie. Gdyby to nie zaistniało, człowiek być może nie zwróciłby się do Boga 4 .

Tego typu doświadczenia nie omijają również ludzi sprawiedliwych, o czym poucza np. Orygenes, według którego cierpienie prowadzi do oczyszczenia. W takim sensie wszelkie utrapienia, jakich doznaje człowiek w tym życiu, są znakiem miłości i dobroci Boga, który doświadcza ludzi, aby ich oczyścić z grzechu. Kto zaś nie jest przez Boga doświadczany w taki sposób, a ma świadomość popełnionych grzechów, winien, zdaniem Orygenesa, szukać dobrowolnych umartwień, które posłużą ekspiacji. Stąd jeśli są one dobrowolnie podjęte w duchu pokuty, mogą przebłagać Boga i sprowadzić oczyszczenie, jakiego nabywa się przez karcenie i doświadczenia zesłane przez Boga na tych, których On kocha i których chce zbawić. W tym świetle cierpienia są znakiem miłości dobrego Boga, wyrazem Jego łaski, Jego wychowawczego działania. Należałoby więc dziękować za nie Bogu, prosić o nie jak o łaskę i dobrodziejstwo. Człowiek Boży więc nie tylko godzi się na utrapienie, które Bóg na niego zsyła, ale wręcz będzie go szuka15.

Interesująca w tym względzie jest refleksja F. Drączkowskiego o radości i wdzięczności za cierpienia. W ramach rozważań autor daje odpowiedź na pytanie: Co dawało siłę pierwszym chrześcijanom do przeżycia cierpienia, na które spoglądali jako na dar dobroci Bożej? Dar przyjmuje się radośnie. Tak więc przyjmowali pierwsi chrześcijanie cierpienie i doświadczenia z ręki Boga. Zdaniem wspomnianego badacza, źródłem ich mocy w cierpieniach była wiara w przyszłą nagrodę, jak również - i to przede wszystkim - miłość $\mathrm{Boga}^{6}$.

2 Por. tamże, s. 16.

3 Por. tamże.

${ }^{4}$ Por. F. Drączkowski, Cierpienie i śmierć w nauce Ojców Kościoła, w: Cierpienie i śmierć, dz. cyt., s. 33.

5 Por. tamże, s. 33, 36, 37.

${ }^{6}$ Por. tamże, s. 41. 
Aby potwierdzić prawdę o tym, że miłość jest źródłem mocy w przeżywaniu cierpienia, F. Drączkowski opiera się na jednej z homilii św. Augustyna, który przywołuje historię św. Pawła. Cytując jego własne słowa ( 2 Kor 6,$4 ; 11,24,25)$, przypomina wszystkie cierpienia i utrapienia, które znosił Paweł Apostoł: „Od Żydów otrzymałem pięć razy po 40 plag bez jednej. Trzykroć byłem smagany rózgami, raz byłem kamienowany, trzy razy przeżyłem rozbicie okrętu, dniem i nocą na głębi morskiej”. Święty Augustyn pyta: „Skąd ta siła i moc św. Pawła do zniesienia wszystkich tych udręk i cierpień?” Według Augustyna siłą tą była doskonała miłość do Chrystusa, o której św. Paweł pisał: ,ani śmierć, ani życie, ani aniołowie, ani Zwierzchności, ani inne rzeczy teraźniejsze, ani przyszłe, ani Moce, ani co wysokie, ani co głębokie, ani jakiekolwiek inne stworzenie nie zdołają go odłączyć od miłości Boga, która jest w Jezusie Chrystusie” (Rz 5,38-39), „Wszystko bowiem, co srogie i straszne - pisze św. Augustyn - miłość czyni w ogóle łatwym i prawie żadnym" ". Oto dlaczego to jarzmo jest słodkie, a brzemię lekkie. Jeśli jest ono „trudne dla tych nielicznych, którzy je wybrali, to łatwe dla wszystkich, co je pokochali [...], drogi, które są twarde dla trudzących się, łagodnieją dla kochających [...]"8. Tak więc miłość Boża, miłość doskonała sprawia, że jarzmo Chrystusowe jest słodkie, a brzemię lekkie. Tak jak dla matki kochającej swe dziecko wszelkie trudy przy jego wychowaniu są łatwe, tak miłość Boga sprawia, że codzienne krzyże i utrapienia stają się lekkie ${ }^{9}$.

\section{Wpływ miłości na przeżywanie cierpienia w refleksji ojców Kościoła}

Ojcowie Kościoła wypowiadają się też na temat wpływu miłości na przeżywanie śmierci. W związku z tym Drączkowski zauważa, że apologeci chrześcijańscy akcentowali podwójną śmierć: duszy i ciała. Tylko ta pierwsza jest groźna i niebezpieczna. Dla męczenników mocą pozwalającą przetrwać męki i katusze była perspektywa życia wiecznego, z Bogiem w niebie. Dlatego stosunek chrześcijanina do śmierci zależy od tego, do jakiego stopnia zjednoczył się z Bogiem na Ziemi poprzez doskonałą miłość. Klemens Aleksandryjski wspomina o doskonałej i niedoskonałej motywacji śmierci męczeńskiej. Ta ostatnia ma miejsce wtedy, gdy wybiera się ją z posłuszeństwa lub lęku przed karą wieczną. Miłość doskonała sprawia, że męczeństwo staje się doskonałe.

\footnotetext{
${ }^{7}$ Augustyn, Wyznania 70, 3, thum. J. Jaworski, w: F. Drączkowski, Cierpienie i śmierć w nauce Ojców Kościoła, dz. cyt., s. 41.

${ }^{8}$ F. Drączkowski, Cierpienie i śmierć w nauce Ojców Kościoła, dz. cyt., s. 41.

9 Por. tamże, s. 41, 42.
} 
Miłość ta, jego zdaniem, przepełnia bez reszty i całkowicie duszę chrześcijanina. Doskonały chrześcijanin, przyjaciel Boga, ,zawsze kocha Boga i tylko na Niego jest całkowicie ukierunkowany"10. Miłość Boga bez reszty go wypełnia i wszystko mu zastępuje. Dlatego według Klemensa Aleksandryjskiego „,złowiek doskonale miłujący Boga nie podlega pożądaniom ani jakimkolwiek pragnieniom, nie odczuwa też w duszy niczego innego (gdyż ma wszystko), trwając przez miłość w zjednoczeniu z tym, który jest przedmiotem jego ukochania"11. Uczucie to ogarnia wierzącego jak płomień i czyni zdolnym do radosnego zniesienia wszystkich cierpień na rzecz Boga, którego ukochał bez reszty. Pragnie on śmierci męczeńskiej po to, by połączyć się z Chrystusem. Zdaniem Klemensa Aleksandryjskiego, taką postawę reprezentował św. Paweł, który stwierdził: ,„...] albowiem życie moje - to Chrystus, śmierć to mój zysk [...] pożądam gorąco śmierci i zjednoczenia z Chrystusem, to o wiele lepsze, ale moje dalsze pozostanie $\mathrm{w}$ granicach cielesności potrzebne jest ze względu na was" ${ }^{12}$. Miłość Boga sprawia, że owładnięty nią wierzący radośnie odpowiada na Boże żądania, nie odczuwając przy tym ani żalu do Boga, ani do prześladowców. Wręcz przeciwnie, „będzie raczej chciał wdzięczności dla Tego, który mu dał sposobność do opuszczenia tego życia, i dla tego, który zastawił dla niego zasadzkę"13. Stąd wierzący, który osiągnął etap miłości doskonałej, pragnie śmierci jednoczącej z Bogiem.

Ze wspartych na nauczaniu ojców Kościoła rozważań F. Drączkowskiego wynika, że kluczem do rozwiązania problemu tak cierpienia, jak i śmierci, jest doskonała miłość Boga i bliźniego. Agape teleia jest siłą, która sprawia, że każdy krzyż jest łatwy i lekki. Miłość uwalnia od lęku przed śmiercią i uzdalnia do ochoczego i radosnego jej przyjęcia. Dla tych, którzy wznieśli się na wyżyny miłości doskonałej, cierpienie i śmierć są drogą prowadzącą do szczęścia i radości wiecznej ${ }^{14}$.

\section{Wpływ miłości na przeżywanie cierpienia z psychologicznego i teologicznego punktu widzenia}

Wydaje się, że warto również ukazać psychologiczny aspekt omawianego zagadnienia. Posłuży do tego analiza silnych duchowo osobowości. W ich

10 Por. Klemens Aleksandryjski, Dywany, VI 71,4, tłum. J. Pliszczyńska, I-VIII, Lublin 1972, cyt. za F. Drączkowski, Cierpienie i śmierć w nauce Ojców Kościoła, dz. cyt., s. 46.

${ }^{11}$ Por. Klemens Aleksandryjski, Dywany, VI 72, 1, dz. cyt., s. 46.

12 Por. Klemens Aleksandryjski, Dywany III 65, 2, por. Flp 1,23-24, w: F. Drączkowski, Cierpienie i śmierć w nauce Ojców Kościoła, dz. cyt., s. 47.

13 Por. Klemens Aleksandryjski, Dywany IV 14, 1, dz. cyt.; por. Dywany IV 13,1, dz. cyt., s. 47.

14 Por. F. Drączkowski, Cierpienie i śmierć w nauce Ojców Kościoła, dz. cyt., s. 48. 
przypadku nie tylko miłość, ale i samotne cierpienie daje energię do działania. Na podstawie badań stwierdzono, że osoby takie pragną przezwyciężyć swoją graniczną sytuację, a kompensując siłą woli dyskomfort życiowy, wznoszą się ponad przeciętność i osiągają zadziwiające wyniki ${ }^{15}$. W uzasadnieniu istotnego wpływu miłości na przeżywanie cierpienia i śmierci z psychologicznego punktu widzenia posłużono się poglądem wyrażonym w deklaracji Kongregacji Nauki Wiary dotyczącym kwestii eutanazji. Rozważając problem eutanazji w kontekście miłości, starano się zbadać zachowanie się chorych w sytuacjach narastającego cierpienia. W związku z tym we wspomnianej deklaracji natarczywe narzekanie chorych, którzy wzywają czasem śmierci, nie jest postrzegane jako przejaw prawdziwej woli eutanazji, prawie zawsze chodzi o pełne niepokoju wzywanie pomocy i miłości ${ }^{16}$.

Tym, co przybliża i jeszcze lepiej pomaga zrozumieć tajemnicę przyjmowania cierpienia z pomocą miłości, jest sama miłość Boga do człowieka. Nie można jej porównać z żadną inną miłością. Najbardziej spektakularnym jej przykładem jest zbawcza ofiara Jezusa Chrystusa. W ten sposób Bóg zaangażował się w dzieje każdej ludzkiej istoty. Na ten temat zwrócił uwagę w swojej drugiej encyklice Dives in misericordia św. Jan Paweł II: „To miłość Boga, poprzez czyn zbawczy Jednorodzonego Syna, dowodziła w sposób wyjątkowy swej partycypacji w losie człowieka. Życie Chrystusa było pochodem miłości, która ogarnia każdego człowieka, zwłaszcza w jego cierpieniu, ograniczoności, słabości fizycznej i moralnej"17. Jego męka na Krzyżu jest aktem objęcia człowieka i świata miłością i przyjaźnią z Bogiem w zbawczej ekonomii ${ }^{18}$. Chrystus dowiódł, że przez własne cierpienie wkracza w powszechne cierpienie ludzkości i przekształca je poprzez miłość w zbawczą energię $(1 \mathrm{Kor} 13,7)^{19}$. W tym kontekście:

cierpienie ludzkie osiągnęło swój zenit w męce Chrystusa. Równocześnie zaś weszło ono w całkowicie nowy wymiar i w nowy porządek: zostało związane z miłością, [...], która tworzy dobro wyprowadzając je również ze zła, wyprowadzając

15 Por. E. Sujak, Rozważania o ludzkim rozwoju, Kraków 1975, s. 54 i n., w: S. Rosik, Tajemnica ludzkiego cierpienia a moc Chrystusowego krzyża, w: Cierpienie i śmierć, dz. cyt., s. 70.

${ }_{16}$ Por. Deklaracja Kongregacji Nauki Wiary o eutanazji, rozdz. II, nr. 1, http://www.opoka.org. pl/biblioteka/W/WR/kongregacje/kdwiary/zbior, s. 2, [dostęp: 21.09.2016], w: S. Rosik, Tajemnica ludzkiego cierpienia a moc Chrystusowego krzyża, dz. cyt., s. 71. Por. też Katechizmus Katolíckej Cirkvi, nr. 2279, Trnava 1999, s. 554.

${ }^{17}$ Por. Jan Paweł II, Dives in misericordia, nr 3, Wrocław 1980, w: art. cyt. w: Cierpienie i śmierć, dz. cyt., s. 76.

18 Por. Jan Paweł II, Salvifici doloris, nr 17, Wrocław 1984. Por. też: http://www.opoka.org. pl/biblioteka/W/WP/jan_pawel_ii/listy/salvifici_doloris, s. 6-7 [dostęp: 21.09.2016], w: S. Rosik, Tajemnica ludzkiego cierpienia a moc Chrystusowego krzyża, dz. cyt., s. 76.

19 Por. Jan Paweł II, Redemptor hominis, 8, 10, Wrocław 1986, s. 25, 30, w: S. Rosik, Tajemnica ludzkiego cierpienia a moc Chrystusowego krzyża, dz. cyt. 
poprzez cierpienie tak, jak najwyższe dobro Odkupienia świata zostało wyprowadzone z Krzyża Chrystusa i stale bierze z niego swój początek. Krzyż Chrystusa stał się źródłem, z którego biją strumienie wody żywej (J 7,37-38) ${ }^{20}$.

Kwestię przyjęcia cierpienia jako aktu nadziei, w czym również może pomóc szczera i autentyczna miłość, Jan Paweł II rozważał, odwołując się do zbawczej śmierci Jezusa, podjętej z miłości do ludzi. W związku z tym stwierdził, że skoro człowiek nie może w doczesnym życiu uwolnić się od cierpienia, może je pokonać, powiązawszy je z cierpieniem Jezusa Chrystusa, i przez to uczynić je sensownym, to znaczy zbawczym. Nadzieja wyzwolenia płynie więc z możliwości partycypacji w Krzyżu Chrystusowym ,przez który stało się nam zbawienie"21.

Kontynuując rozważania na temat wpływu miłości na przeżywanie cierpienia i śmierci, przypomina się za św. Janem Pawłem II, że: „W krzyżu Chrystusa nie tylko odkupienie dokonało się przez cierpienie, ale samo cierpienie zostało też odkupione"22. Stąd ludzkie cierpienie, dzięki Jezusowi, który jest wcieleniem doskonałej miłości, przestaje być zagadką, absurdem, klęską, ale staje się powołaniem do włączenia się w Chrystusową ofiarę, zbawiającą świat. Dlatego należy je potraktować jako ofiarę złożoną w duchu miłości do Boga i bliźnich i w ten sposób zespolić się z Chrystusową miłością miłosierną ${ }^{23}$. Oznacza to, jak naucza św. Jan Paweł II, że cierpienie ma charakter twórczy i zawsze może związać się z odkupieńczym dziełem Chrystusa. W świetle powyższych stwierdzeń nie musi być ono ani nie jest klęską, lecz siłą i szczególnym oparciem wzmacniającym dobro ${ }^{24}$. Na drodze Chrystusowego Krzyża życie i śmierć, szczęście i cierpienie doznają uświęcenia i nabierają nowego sensu $^{25}$. Cierpienie staje się owocne i płodne. Przynosi dojrzałość, mądrość, dobroć, wrażliwość, solidarność ${ }^{26}$. Bez niego - stwierdza św. Jan Paweł II -

20 Por. Jan Paweł II, Salvifici doloris, nr 18, w: Rosik, Tajemnica ludzkiego cierpienia a moc Chrystusowego krzyża, dz. cyt., s. 77.

${ }^{21}$ S. Rosik, Tajemnica ludzkiego cierpienia a moc Chrystusowego krzyża, dz. cyt., s. 78.

22 Por. Jan Paweł II, Salvifici doloris, nr 19, w: S. Rosik, Tajemnica ludzkiego cierpienia a moc Chrystusowego krzyża, dz. cyt., s. 79.

${ }^{23}$ Por. Jan Paweł II, Cierpienie świadome, przyjęte z wiara [...] Do chorych (15.08. 1983), „L'Osservatore Romano” 4(1983), nr 7-8, s. 11, w: S. Rosik, Tajemnica ludzkiego cierpienia a moc Chrystusowego krzyża, dz. cyt., s. 79.

24 Por. Jan Paweł II, Salvifici doloris, nr 25, w: S. Rosik, Tajemnica ludzkiego cierpienia a moc Chrystusowego krzyża, dz. cyt., s. 81.

${ }^{25}$ Por. Sobór Watykański II, Konstytucja duszpasterska o Kościele w świecie współczesnym Gaudium et spes, nr22, w: tenże, Konstytucje, dekrety, deklaracje, Poznań 1986, s. 553, w: Rosik, Tajemnica ludzkiego cierpienia a moc Chrystusowego krzyża, dz. cyt., s. 81.

${ }^{26}$ Por. Jan Paweł II, Krzyż Chrystusa - fundamentem nadziei. Audiencja generalna (31.03. 1983), „L'Osservatore Romano” 4(1983), nr 3, s. 18, w: Rosik, Tajemnica ludzkiego cierpienia a moc Chrystusowego krzyża, dz. cyt. 
świat byłby uboższy o przeżycie ludzkiego współczucia, o doświadczenie nieegoistycznej, niekiedy wręcz heroicznej miłości ${ }^{27}$.

W świetle wiary więc - „ból rodzenia” jest owocny, ponieważ Bóg przekształca go w owocowanie dobra. Dlatego św. Jan Paweł II stwierdził: „,szukajcie sensu swoich cierpień w uświęcaniu własnego życia, życia rodzin i wspólnot, w których żyjecie" ${ }^{28}$. Cierpienie więc jest nie tylko osobistą pokutą, zadośćuczynieniem za grzechy własne i innych, ale i bramą, przez którą wkracza się do niebieskiej ojczyzny ${ }^{29}$. Stąd nad życiem i cierpieniem chrześcijanina unosi się blask nadziei. W związku z tym św. Jan Paweł II napisał, że: „człowiek nie odnajduje sensu cierpienia na swoim ludzkim poziomie, ale na poziomie cierpienia Chrystusa. Równocześnie jednak z tego Chrystusowego poziomu ów zbawczy sens cierpienia zstępuje na poziom człowieka i staje się poniekąd wyrazem jego własnej odpowiedzi. Wówczas też człowiek odnajduje w swoim cierpieniu pokój wewnętrzny, a nawet duchową radość" ${ }^{30}$. Stąd Krzyż Chrystusa, w którym zawiera się i krzyż człowieka, jest znakiem miłości, która cierpi, ale i która przynosi wyzwolenie ${ }^{31}$.

\subsection{Cierpienie a sakrament namaszczenia chorych}

W ramach rozważań na temat wpływu miłości na przeżywanie cierpienia oraz śmierci należy podjąć refleksję dotykającą sensu cierpienia i śmierci w świetle liturgii sakramentu namaszczenia chorych i wiatyku. Aspekt ten pojawia się w chrześcijańskim spojrzeniu na chorobę i cierpienie. Na podstawie biblijnej przesłanki słusznie się zauważa, że związane są one nie tylko z samym grzechem, ale z faktem, że człowiek jest jedynie stworzeniem. W konkretnym wypadku choroba i związane z nią cierpienie jest zawsze tajemnicą i trudno dać jedną i trafną odpowiedź na pytanie o ich źródło, gdyż ukryta jest ona $\mathrm{W}$ niepojętej opatrzności Bożej, do której można się zbliżyć tylko przez wiarę, ufność i miłość. Wyłącznie one mogą nadać ludzkiemu cierpieniu praw-

27 Por. Jan Paweł II, Także $i$ wy nas obdarzacie. Spotkanie z chorymi, starszymi, ułomnymi (11.09. 1983, Wiedeń), „L’Osservatore Romano” 9(1983), s. 10, w: S. Rosik, Tajemnica ludzkiego cierpienia a moc Chrystusowego krzyża, dz. cyt.

${ }^{28}$ Por. Jan Paweł II, W cierpieniu spotykamy się z tajemnica śmierci i zmartwychwstania Chrystusa”, s. 4. Por. tenże, „Cierpienie stawia was w sercu Tajemnicy Odkupienia” (Homilia 5.06. 1983), „L’Osservatore Romano”, 4(1983), nr 5-6, s. 32, w: S. Rosik, Tajemnica ludzkiego cierpienia a moc Chrystusowego krzyża, dz. cyt., s. 82.

${ }^{29}$ Por. Paweł VI, Adhortacja apostolska Cum proximus (14.09.1963), ,Acta Apostolice Sedis” 55(1963) 733, w: S. Rosik, Tajemnica ludzkiego cierpienia a moc Chrystusowego krzyża, dz. cyt.

${ }^{30}$ Por. Jan Paweł II, „Salvifici doloris”, nr. 26, w: http://www.opoka.org.pl/biblioteka/W/WP/ jan_pawel_ii/listy/salvifici_doloris, s. 12, [dostęp: 14.09.2016], w: S. Rosik, Tajemnica ludzkiego cierpienia a moc Chrystusowego krzyża, dz. cyt.

31 Por. S. Rosik, Tajemnica ludzkiego cierpienia a moc Chrystusowego krzyża, dz. cyt., s. 83. 
dziwy i ostateczny sens i przez to uczynić je wartością w wymiarze zarówno osobistym, jak i społecznym oraz eklezjalnym ${ }^{32}$.

Podobne są spostrzeżenia C. Krakowiaka. Wobec tego podkreśla on istotną rolę wiary i miłości, ale bardziej w powiązaniu z osobą Jezusa Chrystusa. Według niego cierpienie nabiera właściwego i wyższego sensu dzięki wierze w Jezusa Chrystusa - staje się łatwiejsze do zrozumienia. Chrześcijanin, walcząc z chorobami i z wszelkiego rodzaju cierpieniami, powinien być także gotowy do ich akceptacji i złączenia się w nich z męką Chrystusa, aby „dopełnić to, czego nie dostaje cierpieniom Chrystusa, dla zbawienia świata" (Kol 1,24; Rz 8,19-21). W ten sposób jego cierpienie nie jest już jedynie złem, które należy zwalczać, lecz staje się wartością. Może zarówno przynosić dobro duchowe cierpiącemu, jak też przyczyniać się do zbawienia innych. Osiągnięcie takiego stanu świadomości możliwe jest jednak tylko poprzez wiarę i zjednoczenie z Chrystusem przez miłośćc 33 .

\subsection{Przeżywanie cierpienia w zjednoczeniu z Jezusem Chrystusem}

Aby lepiej zrozumieć dynamikę miłości w kontekście przeżywania cierpienia i śmierci, należy podkreślić ścisłe ich odniesienie do osoby Jezusa Chrystusa. Dzięki temu łatwiej zrozumieć pogląd, że tajemnica cierpienia i śmierci nabiera pełnego sensu w świetle męki, śmierci i zmartwychwstania Chrystusa, który przyjął na siebie cierpiętliwą naturę ludzką, aby ją uzdrowić i zbawić. Do chwili uwielbienia swego człowieczeństwa Chrystus żył „w ciele podobnym do ciała grzesznego" (Rz 8,3) i był reprezentantem grzesznej ludzkości, podległej cierpieniom i śmierci (por. Rz 6,9-10). Posłuszny woli Ojca i z miłości do ludzi dobrowolnie przyjął Krzyż i złożył w ofierze swoje życie za zbawienie świata ${ }^{34}$.

Niezgłębiona miłość Jezusa do każdego człowieka stworzonego na obraz Boży i Boże podobieństwo, która jest podstawą zbawczego dzieła, to istotny fundament niezbędny do zjednoczenia z Bogiem w próbie cierpienia i „śmierci sobie" na drodze do świętości. Szczególnym sprawdzianem świętości człowieka jest jego stosunek do cierpienia. Chrześcijanin dążący do zjednoczenia z Bogiem powinien nie tylko przyjąć je jako wyraz woli Boga, lecz je uświęcić. Wiedziała o tym bł. Marcelina Darowska ${ }^{35}$. Według niej cierpienie staje

32 Por. C. Krakowiak, Sens cierpienia i śmierci w świetle liturgii sakramentu namaszczenia chorych $i$ wiatyku, w: Cierpienie i śmierć, dz. cyt., s. 88.

33 Por. tamże, s. 89.

34 Por. C. Krakowiak, Sens cierpienia i śmierci w świetle liturgii sakramentu namaszczenia chorych $i$ wiatyku, s. 90-91.

35 Marcelina Darowska, z domu Kotowicz (ur. 16 stycznia 1827 w Szulakach na Podolu [dawne województwo Racławskie], zm. 5 stycznia 1911 w Jazłowcu) - polska zakonnica katolicka, 
się sprawdzianem miłości podczas prób osiągania zjednoczenia z Bogiem poprzez „śmierć sobie”. Jezus, który dał przykład cierpienia z miłości do każdego człowieka, tak bardzo ukochał ludzi, że aż poniósł za nich śmierć. Dzieło zbawcze mogło się spełnić dzięki ludzkiej naturze zjednoczonej z boską naturą ,wcielonego Słowa”. W chwili spełniania dzieła zbawczego na Krzyżu Jezus jest też człowiekiem, którego ludzka natura trwa w Bogu. Z uwagi na to, że jest Osobą Boską, Jego miłość ku ludziom to bezgraniczna miłość Boga mocniejsza od wszelkiego zła. Miłość okazana przez śmierć i cierpienie Syna Bożego w Jego ludzkiej naturze jest ze swej strony siłą prowadzącą człowieka w kierunku miłości Boga i bliźniego. W męce i śmierci ofiarnej Chrystusa ujawniła się również miłość ogarniająca każdego człowieka ${ }^{36}$. Dlatego też chrześcijanin przyjmujący cierpienie odpowiada na miłość uczuciem podobnym do Chrystusowego. Bóg wybiera niektórych ludzi, aby dawali świadectwo swej miłości do Niego poprzez życie przytłoczone licznymi utrapieniami. Wobec tych, których doświadcza cierpieniem, objawia głębszy zamiar i wówczas cierpienie staje się szczególnym rodzajem powołania. Marcelina Darowska ukazuje je z jednej strony jako wyraz miłości Jezusa, z drugiej zaś jako stan, który powinien pomagać człowiekowi w refleksji nad sobą i prowadzić go do Boga jako pełni szczęścia. Widzi ona w tajemnicy Chrystusa wyraźny związek cierpienia z miłością, zwłaszcza wówczas, gdy osiągnęło swój szczyt, tzn. na Krzyżu. To z kolei prowadzi do stwierdzenia, że w ten sposób cierpienie ujawniło swój nowy wymiar, jakim jest miłość. Rozumienie cierpienia jako znak miłości Jezusa powinno prowadzić chrześcijanina do przyjęcia wobec niego postawy maksymalistycznej, polegającej na gotowości woli do przyjmowania cierpienia $\mathrm{w}$ duchu miłości (i wynagrodzenia, w przypadku księży sercanów), której źródła należy szukać w Krzyżu Chrystusa. Właściwy sens Krzyża można zrozumieć wtedy, gdy ma się miłośćc ${ }^{37}$.

Zjednoczenie z Bogiem w niebie jest przygotowane dla tych, którzy chcą i umieją dźwigać swój krzyż; którzy przyjmują cierpienie z miłością. Prag-

współzałożycielka i druga przełożona generalna Zgromadzenia Sióstr Niepokalanego Poczęcia NMP (niepokalanki), błogosławiona Kościoła Rzymskokatolickiego i mistyczka. Do godności błogosławionych wyniósł w Rzymie Marcelinę Darowską św. Jan Paweł II dnia 6 października 1996 roku, w: https://pl.wikipedia.org/wiki/Marcelina_Darowska, s. 1 [dostęp: 15.09.2016].

${ }^{36}$ Por. M. Darowska, Rekolekscje o ufności z 1882 r., nauka 3; Rekolekcje dla wychowanek, czerwiec 1880 r., nauka 4: O cierpieniu i nebezpieczeństwach życia, t. 46., s 178, 190, w: S. Urbański, Zjednoczenie z Bogiem w próbie cierpienia i „śmierci sobie“ wedlug nauki Marceliny Darowskiej, w: Cierpienie i śmierć, dz. cyt., s. 99, 100.

37 Por. M. Darowska, Konferencje, seria 2, konferencja 32: O wspótcierpieniu z Panem Jezusem - Wielki Post 1882 r. Por. też Konferencje, seria 7, konferencja 45: O poście, 9 II 1910 r.; seria 3, konferencja 7: O umartwieniu i skupieniu wielkpostnym, 9 III 1884 r., t. 42, s 143-145, w: S. Urbański, Zjednoczenie z Bogiem w próbie cierpienia i ,śmierci sobie “ wedlug nauki Marceliny Darowskiej, dz. cyt., s. 99-100. Por. Konstytucje SCJ, rozdz. 3, nr. 6, 7, Kraków 1983, s. 4-5. 
nieniem M. Darowskiej było rozmiłować ludzi w cierpieniach. Dlatego tak wiele nauk rekolekcyjnych, w tym szczególnie wielkopostnych, poświęciła temu tematowi, chcąc, aby Wielki Post był corocznie dziełem szczególnego umartwienia wypływającego z miłości ku cierpiącemu Chrystusowi. Autorka pragnęła również, aby w tym okresie przedmiotem codziennego rozmyślania sióstr niepokalanek była męka Pańska, przez której rozważanie człowiek poznaje miłość będącą motywem męki i śmierci Chrystusa na Krzyżu. Miłość, która znalazła swój wyraz w cierpieniu i śmierci, sprawia, że Chrystus żyje $\mathrm{w}$ tym, kogo umiłował. W związku z tym autorka nieustannie przypominała, aby na cierpienie własne i cierpienie Chrystusa patrzeć przez miłość, gdyż dopiero przez nią można odkryć jego właściwą wartość. Chrystus umożliwia wszelkiemu ludzkiemu cierpieniu uczestnictwo w swoim i dlatego każdy chrześcijanin zjednoczony z Nim w Jego męce poprzez miłość może dawać świadectwo własnego cierpienia. W ten sposób - oczyszczone z pierwiastka egoistycznego i złożone jako ofiara - silnie łączy z Chrystusem, a jednocześnie staje się sprawdzianem miłości człowieka do Niego ${ }^{38}$.

\section{Przeżywanie cierpienia w ujęciu Marceliny Darowskiej i według Jana Leona Dehona}

W miarę rozwoju życia wewnętrznego M. Darowska w coraz większym stopniu podkreślała, że źródłem siły potrzebnej do przeżywania cierpienia jest dynamika miłości. Niezbędna jest zwłaszcza na drodze oświecenia, gdzie następuje przyzwyczajenie się do cierpień i miłosne przylgnięcie do nich. Jest to możliwe, ponieważ cierpienia stają się dla człowieka ,nieodstępnym przyjacielem”. Dopiero na drodze zjednoczenia chrześcijanin przyjmuje je chętnie i nawet ich pragnie. Dlatego osoby będące na tym etapie życia wewnętrznego mogą pragnąć męczeństwa duchowego, które jest wynagrodzeniem Bogu za popełnione grzechy, i dlatego M. Darowska przypisuje jemu większą wartość i rolę niż męczeństwu fizycznemu. Jeśli jest przeżywane w łączności z Bogiem, daje też człowiekowi głębokie odczucie szczęścia ${ }^{39}$.

Warto również zwrócić uwagę na różnicę, jaka występuje pomiędzy cierpieniem a grzechem. Darowska rozpatruje ten ostatni jako brak miłości, nazy-

${ }^{38}$ Por. M. Darowska, List do matky Józefy Karskiej z 27 I 1856 r. (P. 4.1III.20), t. 10, s. 85-86; Konferencje, seria 7, konferencja 46, 13 V 1910 r., w: S. Urbański, Zjednoczenie z Bogiem w próbie cierpienia i ,śmierci sobie“ wedlug nauki Marceliny Darowskiej, dz. cyt., s. 100-101.

39 Por. M. Darowska, Konferencje, seria 4, konferencja 6: Stowo wielkopostne - Popielec 1889 r.; Por. też M. Darowska, Konferencje, seria 7, konferencja 12. O Wielkim Poście, 16 II 1902, w: S. Urbański, Zjednoczenie z Bogiem w próbie cierpienia i „śmierci sobie“ wedtug nauki Marceliny Darowskiej, dz. cyt., s. 102-103. 
wa go „policzkiem dla miłości Boga”. Człowiek bowiem odpowiedział na nią swoją zarozumiałością, zuchwalstwem, niewdzięcznością, a przede wszystkim nienawiścią i odwróceniem się od Niego. W tym świetle M. Darowska ukazuje różnorodne postawy wobec cierpienia, podkreślając jednocześnie, że jego wynik zależy od tego, co jest naszą miłością. Mówiąc o różnicy między cierpieniem i grzechem, podkreśla, że w początkowej fazie duchowego rozwoju cierpienie trzeba przyjąć jako karę za grzechy. Jednakże ma ono służyć nawróceniu człowieka. Powinno prowadzić do odbudowania dobra w człowieku i dlatego M. Darowska uważa, że należy je przyjąć z miłością, ponieważ uczucie miłości kary w nadzwyczajny sposób jedna Boga. W następnym okresie rozwoju duchowego musi być ono zastąpione cierpieniem z miłości, jeżeli bowiem człowiek przeniknięty jest prawdziwie nadprzyrodzoną miłością Boga, cierpienie nie ma dla niego wielkiej wagi. Oczywiście ludzki ból nie zanika, ale przyjmuje się go z radością, ponieważ w ten sposób sam Chrystus może cierpieć w nas i chwalić przez to Ojca ${ }^{40}$.

Marcelina Darowska podjęła także zagadnienie cierpienia i pokuty. Jej zdaniem, uświadamia ona człowiekowi jego miejsce w stosunku do Boga, odkrywając niewystarczalność istoty ludzkiej i wykazując wszechmoc oraz miłość Stwórcy. Pojąwszy to, należy cierpieć w duchu miłości, w niej bowiem jest zawarta pokora, a jeśli tylko chrześcijanin, który z natury kocha siebie, poczuje swoją niegodność, stara się „zmazać siebie przed Bogiem”. Pokora zatem prowadzi do miłości, ponieważ z uświadomienia sobie przez człowieka własnej niegodności wobec Boga rodzi się wdzięczność, która z kolei daje miłość. I odwrotnie - miłość nie może istnieć bez pokory ${ }^{41}$.

W akcie pokuty natomiast dusza cierpi, uświadomiwszy sobie, że obraziła Boga, i gotowa jest przyjąć najprzykrzejsze konsekwencje, aby tylko wynagrodzić wyrządzone zło. Powstające wtedy w duszy cierpienie wywołuje pragnienie skruchy, zadośćuczynienia za grzech, chęć wyrównania go (o ile to możliwe), a spłacić dług można, jedynie dołączając swe cierpienie do zasług Chrystusa. Dlatego ból skruchy w obliczu cierpień Zbawiciela za każdy grzech ludzki rodzi silne pragnienie cierpienia zadośćuczynnego ${ }^{42}$.

40 Por. M. Darowska, Rekolekcje o milości, 13-18 XI 1877 r., t. 38, s. 139, 142-143. Por. M. Darowska List do matky Józefy Karskiej z 27 VIII 1855 r. (P.4.1.II.15), t. 10, s. 59. Por. M. Darowska, Rekolekcje o ufności z 1822 r., nauka 6, w: S. Urbański, Zjednoczenie z Bogiem w próbie cierpienia $i$,śmierci sobie“ wedlug nauki Marceliny Darowskiej, dz. cyt., s. 105.

${ }^{41}$ Por. M. Darowska, Konferencje, seria 3, konferencja 7: O umartwieniu i skupieniu wielkopostnym, 9 III 1884 r., t. 42, s. 143-144, w: S. Urbański, Zjednoczenie z Bogiem w próbie cierpienia $i$,śmierci sobie“ wedlug nauki Marceliny Darowskiej, dz. cyt., s. 106.

${ }^{42}$ Por. M. Darowska, Konferencje, seria 3, konferencja 7: O umartwieniu i skupieniu wielkopostnym, 9 III 1884 r., t. 42, s. 143-144, w: S. Urbański, Zjednoczenie z Bogiem w próbie cierpienia $i$,,śmierci sobie“ wedlug nauki Marceliny Darowskiej, dz. cyt., s. 106-107. 
Powyższa część rozważań teologicznych M. Darowskiej w istotnej mierze zbieżna jest z ideą wynagrodzenia, która przyświecała księdzu Janowi Leonowi Dehonowi, założycielowi zgromadzenia misyjnego Księży Najświętszego Serca Jezusowego. Potwierdzeniem tej analogii są zwłaszcza dwa numery reguły życia, zawarte w Konstytucjach SCJ:

Zakładając zgromadzenie Oblatów Księży Najświętszego Serca Jezusowego, Ojciec Dehon chciał, aby jego członkowie łączyli swe życie zakonne i apostolskie z wynagradzającą ofiarą, którą Chrystus złożył Ojcu za ludzi. Na tym właśnie polegała specyficzna i pierwotna idea i charakter własny Instytutu [...], oraz posługa, do której został powołany w Kościele. Od swoich zakonników Ojciec Dehon oczekuje, ażeby byli prorokami miłości i sługami pojednania ludzi i świata w Chrystusie (por. 2 Kor 5,18). Tak zaangażowani razem z Nim, by zapobiegać grzechowi oraz brakowi miłości w Kościele i świecie, oddawać będą całym swym życiem, modlitwami i pracami, cierpieniami i radościami kult miłości i wynagrodzenia, którego pragnie Jego Serce ${ }^{43}$.

Bardzo wyraźnie problematyka dynamiki miłości w przeżywaniu cierpienia obecna jest w nauczaniu M. Darowskiej w refleksji poświęconej zjednoczeniu z Bogiem w próbie cierpienia i ,śmierci sobie”. Błogosławiona mówi wtedy o roli miłości w przeżywaniu cierpienia podczas wewnętrznego oczyszczenia. Proces ten nazywa ,śmiercią sobie”, jest on jednak związany ze zmartwychwstaniem Chrystusa w oczyszczonym człowieku, a życie zmartwychwstałe w oczyszczonym człowieku charakteryzuje się m.in. całkowitym połączeniem woli człowieka z wolą Bożą poprzez miłość. Odtąd stanowią jedną wolę - jak określa Darowska - „potężną, niezmienną, spokrewniającą człowieka z Bogiem", a równocześnie przekształcającą go, dającą mu na ziemi początek wieczności. Autorka podkreśla, że to oczyszczenie człowieka - chociaż jako zawierające cierpienie jest samo z siebie aktem negatywnym, ma jednak cel pozytywny, gdyż wiedzie do duchowego zmartwychwstania, do zjednoczenia w miłości z Chrystusem. Miłość osiąga wówczas heroiczny stopień, staje się bezinteresowna, pozbawiona wszelkiej ludzkiej domieszki, jest to miłość duchowa, zakodowana w samym wnętrzu człowieka. Darowska pisze, że jest to „Ogień z nieba niszczący naturę, osobistość, wnoszący śmierć sobie, a z niej życie nadprzyrodzone, rozciągające się na wieczność, jakby jej początek"44. Tak więc miłość nadaje sens oraz wartość ,śmierci sobie" i w ten

${ }^{43}$ Por. Konstytucje SCJ, Kraków 1983, rozdz. 3, nr. 6-7, s. 4-5.

44 Por. M. Darowska, Rekolekcje przed Kapituła 1909 r., nauka 1 (P.19.2.II,3), t. 5, s. 121-122. Wszystkie cytowane w tej części artykułu źródła znajdują się w Archiwum Zgromadzenia Niepokalanego Poczęcia NMP w Szymanowie. Przytaczane tu tomy oznaczają tzw. tomy rzymskie, przygotowane do procesu beatyfikacyjnego M. Darowskiej, a zawierające źródła przepisane $\mathrm{z}$ autografów. 
sposób są one od siebie zależne i wspólnie konstruują autentyczne zjednoczenie z Bogiem. Miłość prowadzi bowiem do Boga, a oczyszczenie siebie poprzez cierpienie jest właśnie drogą do miłości. Innymi słowy, miłość powinna być początkiem i końcem oczyszczenia siebie, a „śmierć sobie” - koniecznym warunkiem miłości ${ }^{45}$. Tylko taka miłość - zdaniem M. Darowskiej - ułatwia ponoszenie związanych $\mathrm{z}$ oczyszczeniem ofiar $\mathrm{w}$ postaci cierpienia, podobnie jak miłość Chrystusa przywiodła Go do złożenia ofiary krzyżowej. Jedyną zaś ofiarą, którą Bóg przyjmuje, jest czystość ludzkiej miłości. Czysta miłość stała się dla J.L. Dehona, założyciela Zgromadzenia Księży Najświętszego Serca Jezusowego, warunkiem praktyki życia oblacji oraz profesji żertwy. Jej istota tkwi głównie w czystej intencji, na wzór Jezusa, który troszczy się przede wszystkim o chwałę Ojca. Założyciel księży sercanów jednoznacznie łączy pragnienie życia miłością czystą ze ślubem żertwy. Miłość czysta stanowi źródło życia immolacji. Przez praktykę czystej miłości człowiek może zrealizować cztery cele ofiary: adorację, dziękczynienie, przebłaganie i prośbę. Wzór czystej miłości odnajdujemy w życiu Jezusa. Jest ona miłością uprzedzającą, wynagradzającą, miłością objawiającą się czynem. Źródłem czystej miłości jest Serce Jezusa. Zagadnienie „,czystej miłości” nie ogranicza się jedynie do relacji pomiędzy człowiekiem a Bogiem. Wykracza ono dalej, wskazując na miłość do Kościoła i świata. „Miłość czysta” ma więc wymiar społeczny ${ }^{46}$.

Człowiek poprzez walkę ze skłonnościami skażonej natury, poprzez cierpienie oraz za pomocą łaski Bożej współkrzyżuje się z Chrystusem. Tajemnica tego współkrzyżowania powoduje, że chrześcijanin przeżywa cierpienie z Chrystusem i dla Niego, zapominając o wszelkim bólu, jaki niesie ze sobą oczyszczenie natury. Potwierdzenie tej prawdy M. Darowska znajduje w perykopie św. Jana, gdzie czytamy: „Jeżeli ziarno pszenicy wpadłszy w ziemię nie obumrze, zostanie tylko samo, ale jeżeli obumrze, przynosi plon obfity" (J 12,24), oraz w zapisanych w Ewangelii św. Łukasza dalszych słowach

45 Por. M. Darowska., Rekolekcje przed kapituła 1909 r. nauka 1. (P.19.2.II.3), t. 5, s. 121-122; Rekolekcje dla sióstr, 30 VII-3 VIII 1879 r., t. 39, s. 33, 48-49, 69; Rekolekcje przed Zielonymi Świętami 1876 r., t. 40, s. 130; Rekolekcje o Najświętszej Maryi Pannie 1886 r., t. 41, s. 84, 147, Konferencje, seria 1, konferencja 14, 26 XII r., t. 42, s. 19, seria 7, konferencja 10: „O umartwieniu”, 1 XI 1901 r., Rekolekcje przed Kapituła 1909 r., nauka 1. (P.19.2.II.3), t. 5, s. 117, w: S. Urbański, Zjednoczenie z Bogiem w próbie cierpienia i ,śmierci sobie“ wedlug nauki Marceliny Darowskiej, dz. cyt., s. 109-110.

46 Por. L. Dehon, Zalecenia i rady Ojca Dehona dla swoich zakonników, w: Dyrektorium duchowe Księży Najświętszego Serca Jezusowego, Warszawa 1997, s. 248-249, 369. Por. J. Gaweł, Ostatni zeszyt „Zapisków codziennych” o. Dehona z 1925, „Informator SCJ” z dnia 23.02.1976, s. 62-69. Por. A. Vassena, ",Prymat ofiarowania się z miłości w charyzmacie o. Dehona na podstawie pierwszych dwóch zeszytów „Dziennika” (Notes Quotidiennes), Dehoniana (wyd. polskie) 3(1979), s. 229-242. Por. L. Dehon, O życiu miłości do Najświętszego Serca Jezusowego, (De la vie d'amour envers le Sacré-Coeur), thum. W. Łukasik, Stopnica 2002, s. 185-186. Por. Konstytucje SCJ, nr 35, s. 21, w: L. Poleszak, Serce Jezusa, Kraków 2010, s. 180-184. 
o „znienawidzeniu” ojca i matki, a nawet swojej duszy (por. Łk 14,26). Darowska ma tutaj na myśli nie tylko oczyszczenie ze zła pochodzącego z zepsutej natury, lecz także z tego wszystkiego, co dobre, lecz czysto ludzkie, przyrodzone, „nienawidzić” bowiem - według Chrystusa - oznacza miłować Boga ponad wszystko, a w nim każdego człowieka, na ile On pozwala. Ta pozorna „nienawiść”, zwłaszcza samego siebie, jest według Darowskiej

rzuceniem ,pod nogi Chrystusowi Panu”, czyli ofiarowaniem siebie, swojego życia, jest „rozmiłowaniem” w Nim (por. Flp 1,21). Dopiero ta „nienawiść” będąca w rzeczywistości miłością prowadzi do oczyszczenia siebie z tego wszystkiego, co przyrodzone, a tym samym do odnowienia życia. Na tym oczyszczeniu natury powstaje „nowy” człowiek. Jeśli jednak ktoś chciał zachować coś dla siebie, coś, co zastrzegł, nie przeżyje szczęścia spotkania z Bogiem, nie będzie jego udziałem zjednoczenie z Nim. Jeśli zaś człowiek żyje z Bogiem, każda chwila jest dla niego nowa, ponieważ życie wewnętrzne otwiera coraz to nowe horyzonty ${ }^{47}$.

Zgłębiając na podstawie teologicznej myśli M. Darowskiej twórczy wpływ miłości na przeżywanie cierpienia, zauważa się jej mistyczny aspekt związany z oblubieńczą miłością Chrystusa. Za M. Darowską wyrażony jest pogląd, że miłość ma swoje prawa i każdy, kto postępuje zgodnie z jej wymaganiami, zacznie w końcu odczuwać ją w swoim sercu. Autorka rozróżnia trzy stopnie miłości. Pierwszy z nich dotyczy świata, polega na tym, by we wszystkim i przez wszystko kochać Boga. Taka miłość Boga nade wszystko zapewnia człowiekowi zbawienie. Drugi stopień - już dla wybranych - jest miłością krzyża i cierpień ze względu na to, że łączą z Chrystusem. Trzeci wreszcie stopień ma miejsce wtedy, gdy człowiek żyje upodobaniem Boga. Aby odczytać Jego wymagania i o nich pamiętać, trzeba ciągle patrzeć w Niego. W miłości tej musi się ciągle poprzez dialog z Nim, czyli modlitwę, pogłębiać jego znajomość, gdyż dopiero Bóg poznany może być naprawdę kochany. Miłości do Boga nie mierzy się bowiem stopniem uczucia, lecz pełnieniem woli Bożej, polegającym na oddaniu się Mu poprzez złożenie całego serca i życia, bez żadnego zastrzeżenia ${ }^{48}$.

U podstaw miłości oblubieńczej leży ,śmierć sobie”, umieranie sobie bowiem jest procesem oczyszczenia. Bóg chce mieć swoją oblubienicę czy oblubieńca całych dla siebie, a życie duchowe to coraz większe oddawanie się

${ }^{47}$ Por. M. Darowska, Rekolekcje przed Kapitula 1909 r. nauka 1 (P.19.2.II.3), t. 5, s. 118 , w: S. Urbański, Zjednoczenie z Bogiem $w$ próbie cierpienia $i$,śmierci sobie” wedlug nauki Marceliny Darowskiej, dz. cyt., s. 110-111.

48 Por. M. Darowska, Rekolekcje o Najświętszej Maryi Pannie 1886 r., t. 41, s. 53-54; Rekolekcje wielkopostne 1880 r., t. 39, s. 126-128; Rekolekcje na uroczystości zakonne 1881 r., t. 40, s. 78, w: S. Urbański, Zjednoczenie z Bogiem w próbie cierpienia i „śmierci sobie“ wedlug nauki Marceliny Darowskiej, dz. cyt., s. 111. 
Bogu. Marcelina Darowska uważa, że na tej drodze Bóg pozwala w jakimś stopniu doświadczać cierpienia, zwłaszcza podczas realizacji drugiego i trzeciego stopnia miłości. Jeśli człowiek nie zachwieje się podczas próby cierpienia towarzyszącej spełnianiu woli Bożej, może powiedzieć o sobie ,już trochę Boga kocham". Jeśli chce być wiernym i kochającym sługą, Bóg sam zaprosi go do relacji bardziej intymnych, oblubieńczych ${ }^{49}$. Jednak być oblubieńcem czy oblubienicą Boga to coś więcej - oblubienica i oblubieniec muszą być czyści, a to wymaga procesu oczyszczenia. Powinni oni raczej wybrać śmierć niż stać się niewiernymi Bogu. Jeżeli człowiek pozostaje wierny powołaniu do miłości oblubieńczej, czyli umiera sobie, by miłość ta była coraz czystsza i coraz pełniejsza, Bóg pozwala mu ją żywo odczuć. Człowiek wierzy wówczas Jego miłości, a wszelkie cierpienia prowadzą go do zjednoczenia z Bogiem w miłości ${ }^{50}$.

\subsection{Rola miłości w przeżywaniu cierpienia u św. Jana od Krzyża}

Prawdę o tym, że cierpienie stanowi konieczną drogę do zjednoczenia się z Bogiem w miłości, potwierdza teologiczna refleksja dotycząca biernej nocy zmysłów i ducha u św. Jana od Krzyża. Opierając się na dziełach św. Jana od Krzyża, o cierpieniu w życiu duchowym nie można mówić bez odniesienia go do miłości, która jest w Bogu i mocą której pragnie On przyciągnąć duszę do siebie. Pociąga to za sobą podjęcie umartwienia, a co za tym idzie, i oczyszczenie zmysłów, co nie jest pogardą dla natury, lecz konsekwencją miłości i podporządkowania wszystkiego zasadom odkrywanym przez intelekt oświecony wiarą ${ }^{51}$. Na pochodzące z zewnątrz oczyszczające cierpienia nocy zmysłów składają się m.in.: krytyka ludzi, nienawiść, prześladowanie, choroby, natomiast cierpienia pochodzące $\mathrm{z}$ wnętrza powodowane są przez: nieczystość duszy, transcendencję Boga, doświadczenia potęgi, naturę, lęki itp. Wszystko to łączy się z ,wielkimi udrękami” w sferze zmysłowej. Dzieje się tak dlatego, że Bóg objawiający się mistykowi jest jednocześnie Światłością i Miłością. Jako Światłość udziela się przez dar rozumu, a jako Miłość - poprzez dar mą-

49 Por. M. Darowska, Rekolekcje dla sióstr, 3.I. 1872 r., t. 37, s. 75-78, w: S. Urbański, Zjednoczenie z Bogiem w próbie cierpienia i ,śmierci sobie“ wedlug nauki Marceliny Darowskiej, dz. cyt.

50 Por. M. Darowska, Rekolekcje na uroczystości zakonne przed Wniebowzięciem 1881 r., t. 40, s. 77; Rekolekcje o Najświętszej Maryi Pannie 1886 r., t. 41, s. 53-54, w: S. Urbański, Zjednoczenie $z$ Bogiem w próbie cierpienia i ,, śmierci sobie“ wedlug nauki Marceliny Darowskiej, dz. cyt., s. 111-112 .

51 Jan od Krzyża, „Noc ciemna”, 2, 11, 1-7, w: Dzieła, tłum. B. Smyrak, Kraków 1986, s. 473-476, w: M. Chmielewski, Cierpienia biernej nocy zmysłów i ducha w doświadczeniu mistycznym Cecylii Działyńskiej, w: Cierpienie i śmierć, dz. cyt., s. 116-117. 
drości. Objawienie Boga miłości dosięga woli i rozpala ją do miłowania, budząc nienasyconą, bolesną tęsknotę za $\mathrm{Nim}^{52}$. Stąd wspomniane wcześniej pod różnymi postaciami cierpienie, które ma za cel oczyszczenie duszy, pochodzi według św. Jana od Krzyża głównie z nadprzyrodzonej miłości Boga. Dusza zraniona miłością Oblubieńca doświadcza rozdarcia duchowego, a nawet w pewnym stopniu śmierci duchowej z pragnienia doskonałego zjednoczenia z Chrystusem. Ponieważ jednak nawet w stanie zaślubin mistycznych łaska nie niszczy natury, toteż Bóg może dopuścić na mistyczną duszę trudy i cierpienia po to, „by powiększała swe zasługi, potęgowała jeszcze więcej swą miłość, lub też w jakimś innym celu". Tak więc udział w tajemnicy krzyża na wyższych stopniach zjednoczenia ma, według św. Jana od Krzyża, trzy formy - są to: rana miłości Oblubieńca, rozdarcie duchowe i uniesienie z miłości ${ }^{53}$. W konsekwencji mistyk mocą Bożej miłości zostaje doprowadzony do zjednoczenia przeobrażającego i odzyskuje tę pełnię człowieczeństwa, jaka jest w Chrystusie. Celem bowiem życia duchowego jest progresywna chrystomorfoza i chrystoformizm, tajemnica zaś Chrystusa odsłania się w pełni w Jego męce, śmierci i zmartwychwstaniu. W związku z tym osiągnięcie chrześcijańskiej doskonałości oznacza totalną chrystyfikację życia. Chrystifykacja zaś oznacza krucyfikację - w myśl słów samego Pana: „Jeśli kto chce iść za Mną, niech się zaprze samego siebie, niech co dnia bierze krzyż swój i niech Mnie naśladuje" (Łk 9,23). W takiej też perspektywie życia duchowego osiągającego najwyższe szczyty zjednoczenia z Bogiem pełniej wyjaśnia się sens cierpienia, które dzięki miłości pomiędzy Bogiem i duszą mistyczną, staje się już nie karą, lecz powołaniem do przeobrażania świata w „cywilizacji miłości”54.

\subsection{Godność człowieka a sens cierpienia}

Uwzględnienie w refleksji teologicznej różnych aspektów dynamiki miłości w przeżywaniu cierpienia umożliwiło podjęcie refleksji na temat praw chorego człowieka we wspólnocie Kościoła, pozwoliło też lepiej poznać człowieka, w tym jego kondycję psychofizyczną, jako warunek refleksji nad nim jako podmiotem prawa. W tym kontekście wypowiedziano się w kwestii Bo-

52 Jan od Krzyża, Noc ciemna, 2, 9, 11, s. 470, w: M. Chmielewski, Cierpienia biernej nocy zmysłów i ducha w doświadczeniu mistycznym Cecylii Działyńskiej, dz. cyt., s. 118.

53 Jan od Krzyża, „Żywy płomień miłości”, 2, 8; 3,18, w: tenże, Dzieła, tłum. B. Smyrak, Kraków 19864, s. 744, 767; tenże, Pieśń duchowa, 7, 1-4; 20 i 21,10, w: tenże, Dzieła, dz. cyt., s. 558, 625; w: M. Chmielewski, Cierpienia biernej nocy zmystów i ducha $w$ doświadczeniu mistycznym Cecylii Działyńskiej, dz. cyt., s. 128, 129.

${ }^{54}$ Cyt. za Janem Pawłem II, Salvifici doloris, nr 30, w: M. Chmielewski, Cierpienia biernej nocy zmystów i ducha w doświadczeniu mistycznym Cecylii Działyńskiej, dz. cyt., s. 130. 
żej miłości do człowieka: „Bóg nie objawił bezpośrednio całej wiedzy o człowieku; objawił [...] swoją miłość do niego i Objawienie pomaga [...] poznać człowieka w świetle tej miłości. Jeżeli więc [uznano] teologię za antropocentryczną, to w tym znaczeniu, iż odśrodkowy punkt objawienia stanowią miłość Boga do człowieka oraz drogi zbawienia człowieka" ${ }^{55}$.

Powyższe słowa mają fundamentalne znaczenie dla rozważanego tutaj zagadnienia. Można powiedzieć, że stanowią pewną bazę do dalszych refleksji na temat roli miłości w przeżywaniu cierpienia, ale przede wszystkim dla tych, którzy o chorych się starają. Objawienie bowiem, a zwłaszcza wcielenie Bożego Syna, co jest równoznaczne ze zjednoczeniem się z każdym człowiekiem, sprawiło, że posługa człowiekowi choremu jest służbą samemu Chrystusowi (por. Mt 25,40). Stąd Kościół darzy miłością wszystkich dotkniętych słabością ludzką, co więcej, w ubogich i cierpiących odnajduje wizerunek swego ubogiego i cierpiącego Zbawiciela, stara się im ulżyć w niedoli i usiłuje służyć w nich Chrystusowi ${ }^{56}$. Stąd też udzielanie owoców odkupienia dokonuje się przede wszystkim przez wiarę, nadzieję i miłość. Cnoty te są tym, co się innym od każdego wierzącego należy. Dlatego też w prawie kościelnym w sposób zupełnie zasadny można mówić o prawach człowieka chorego. Jego specyficzne uprawnienia we wspólnocie kościelnej wynikają z faktu, że jest ona wspólnotą miłości, Mistycznym Ciałem Chrystusa. „Tak więc gdy cierpi jeden członek, współcierpią wszystkie inne członki” (1 Kor 12,26). Słusznie zatem podkreśla Remigiusz Sobański: „Miłość w chrześcijaństwie nie jest czymś dowolnym, jest prawem i obowiązkiem, co więcej, prawem podstawowym. Jeżeli miłość charakteryzuje chrześcijański układ międzyosobowy, to prawo kościelne regulujące relacje międzyosobowe nie może być obojętne wobec tego podstawowego prawa" 57 .

Uznanie człowieka chorego za członka tworzącego wspólnotę miłości we wspólnocie kościelnej pociąga za sobą pewien obowiązek przejawiania miłości do chorego w kontekście klimatu eschatycznego. Choroba oraz niebezpieczeństwo utraty życia tworzą taki specyficzny klimat. Dlatego człowiek staje przed koniecznością dokonania wyboru, podjęcia rozstrzygającej decyzji „zadysponowania sobą" w perspektywie wieczności. Wprawdzie decyzja ta, częstokroć ostateczna i nieodwołalna, musi być wolna i wypływać z głębi oso-

55 Por. B. Haring, Heilender Dienst. Ethische Probleme der modernen Medzin, Mainz 1972, s. 17, 18-21, w: B.W. Zubert, Prawa chorego we wspólnocie Kościoła, w: Cierpienie i śmierć, dz. cyt., s. 131.

56 Por. Sobór Watykański II, Konstytucja dogmatyczna o Kościele Lumen gentium, nr 41, w: tenże, Konstytucje, dekrety, deklaracje, dz. cyt. s. 146-147.

${ }^{57}$ R. Sobański, Człowiek - podmiot praw i obowiazków we wspólnocie Kościoła, w: L. Balcer, Człowiek we wspólnocie Kościoła, Warszawa 1971, s. 71, w: W. Zubert, Prawa chorego we wspólnocie Kościoła, dz. cyt., s. 133. 
bowości, ale to nie wyklucza możliwości „oddziaływania” z zewnątrz, oczywiście w duchu wolności, miłości i prawdy ${ }^{58}$.

W tym kontekście swoistego znaczenia nabierają słowa soborowego Dekretu o apostolstwie świeckich:

Gdziekolwiek znajdują się ludzie, którym brak pokarmu i napoju, ubrania, mieszkania, lekarstw, pracy, oświaty, środków do życia godnego człowieka, ludzie nękani chorobami i przeciwnościami, cierpiący wygnanie i więzienie, tam miłość chrześcijańska winna ich szukać i znajdywać, troskliwie pocieszać i wspierać. Obowiązek ten ciąży przede wszystkim na zamożnych jednostkach i narodach ${ }^{59}$.

Nie są zwolnieni od tego obowiązku zwłaszcza duszpasterze. Odzwierciedliło się to w kościelnym ustawodawstwie: „proboszcz ma w szczególny sposób troszczyć się [...], ażeby katechizować także upośledzonych fizycznie i umysłowo, na ile pozwala na to ich stan. Postanowienie to jest specyfikacją jego funkcji pasterza wspierającego "gorącą miłością» [...] chorych, zwłaszcza bliskich śmierci”'60.

Cenny wkład w rozważanie wpływu miłości na przeżywanie cierpienia wnosi Mieczysław Krąpiec, który stara się dać odpowiedź na pytanie: Czy śmierć jest sensem życia? Na śmierć i miłość spogląda on jako na dwie strony ostatecznego konstytuowania się ludzkiej osobowości. Zdaniem M. Krąpca, bez zaistnienia $\mathrm{w}$ życiu ludzkim, w momencie ustania zmian materii, pełnych warunków miłości - wszelkie porywy wielkiej i prawdziwej miłości byłyby raczej czymś niezrozumiałym, patologicznym, bez perspektywy darowania się pełnego i ostatecznego, już bez determinacji materii (czasu i przestrzeni). Tę - wyzwalającą od atomizujących form działania - naturę miłości przeczuwali genialni poeci i dawali temu wyraz w poezji i wieszczeniu, gdzie wielka miłość łączy się ze śmiercią, gdyż biologicznozmienne trwanie bez miłości nie jest życiem godnym człowieka. Miłość na mocy swej dynamicznej natury dąży do wzrostu, którego najwyższą formą jest „darowanie się ostateczne”. Miłość zatem jako istotna strona ludzkiego życia (ujawniająca się w działaniu) przezwycięża śmierć biologiczną, gdyż dopiero w momencie ustania biologicznego biegu materii zyskuje warunki pełnego wypowiedzenia się, bez ograniczeń, jakie siłą rzeczy narzuca materia ze swymi prawami. W osobowym przeżyciu śmierci jaźń w swym najgłębszym korzeniu: w duszy wiąże się w akcie miło-

58 J. Piper, Śmierć i nieśmiertelność, Znaki Czasu t. 15, Paris 1970, s. 82, w: W. Zubert, Prawa chorego we wspólnocie Kościoła, dz. cyt., s. 133.

59 Por. Sobór Watykański II, Dekret o apostolstwie świeckich Apostolicam actuositatem, nr 8, w: tenże, Konstytucje, dekrety, deklaracje, dz. cyt. s. 387, w: W. Zubert, Prawa chorego we wspólnocie Kościoła, dz. cyt., s. 144.

60 Por. Kódex Kánonického Práva, kán 529 - § 1, Bratislava 1996, s. 203. 
ści z intuicyjnie poznanym, ostatecznie dopełniającym byt przygodny „TY” Transcendentu, ku któremu prowadzi każda realna miłość ludzka ${ }^{61}$.

\subsection{Przykład praktycznego wpływu miłości na przeżywanie cierpienia}

W zrozumieniu praktycznego wpływu miłości na przeżywanie cierpienia i śmierci pomaga prezentacja problemu cierpienia u chorych na schizofrenię. Praktyczna realizacja miłości w służbie we wspomnianym przypadku może posłużyć wszystkim chorym. Każdy człowiek cierpiący w wyniku jakiejkolwiek choroby, która ma wpływ na psychikę, potrzebuje przyjaciela, który będzie mu bliski, który będzie umiał go cierpliwie słuchać i zechce zrozumieć jego inność. Potrzebuje przewodnika, który będzie go bezpiecznie prowadził przez życie, zachowując i bliskość, i odpowiedni dystans ${ }^{62}$.

$\mathrm{Na}$ rolę miłości w przeżywaniu cierpienia jeszcze inne światło rzuca Antoni J. Nowak. Refleksję na ten temat autor opiera na opisie procesu umierania $\mathrm{w}$ aspekcie personalistycznej psychologii głębi. Odwołuje się najpierw do momentu zaistnienia człowieka, wraz z którym zaczęły istnieć: czas, historia, religia, praca. Nie jest wykluczone, że w głębokiej prehistorii jeden „hominid” żył z drugim „hominidem” w zażyłym związku, który można nazwać miłością. Śmierć kochanego „hominida” zmusiła do zadania drastycznego pytania o jej sens. I tak oto miłość byłaby zarówno u początku, jak i u kresu tak filogenezy ${ }^{63}$, jak i ontogenezy ${ }^{64}$. Stare Przymierze mówi nam, że Bóg stworzył człowieka na własny obraz i podobieństwo (por. Rdz 1,26-27). W Nowym Przymierzu czytamy, że Bóg jest Miłością, która umiłowała człowieka i świat (por. J 3,16; $1 \mathrm{~J} 4,16)$. Człowiek zatem został stworzony na obraz i podobieństwo Miłości i dlatego miłość jest nie tylko zasadniczą potrzebą ludzkiego bytowania, ale również jedynie słuszną relacją w świecie osób. Człowiek musi miłować, by nie popaść w rozpacz. Być może, właśnie dlatego A. Nowak twierdzi, że śmierć jest dla człowieka zagadką, dopóki się do niej nie zbliży z postawą miłości. W tym kontekście autor stawia pytanie: Jakie relacje zachodzą pomiędzy miłością i śmiercią? Szukając odpowiedzi, najpierw odwołuje się do kręgów

${ }^{61}$ M. Krąpiec, Czy śmierć jest sensem życia?, w: Cierpienie i śmierć, dz. cyt., s. 157.

${ }^{62}$ S. Seuden, Problem cierpienia u chorych na schizofremie, w: Cierpienie i śmierć, dz. cyt., s. 207.

${ }^{63}$ Filogeneza (z gr. $q v \hat{\text { Kn }}$ - gatunek, ród i $Y \sum V \sum T I C ̧$ - pochodzenie) droga rozwoju rodowego, pochodzenie i zmiany ewolucyjne grupy organizmów, zwykle gatunków. Termin wprowadzony w 1866 roku przez Ernsta Haeckla w Generelle Morphologie der Organismen, https://pl.wikipedia. org/wiki/Filogeneza, s. 1 [dostęp: 20.09.2016].

${ }^{64}$ Ontogeneza, rozwój osobniczy (gr. ontos - byt, będące, istniejące, génezis - pochodzenie) przemiany anatomiczne i fizjologiczne osobnika od powstania $\mathrm{w}$ wyniku rozmnażania do śmierci, w: https://pl.wikipedia.org/wiki/Ontogeneza, s. 1 [dostęp: 20.09.2016]. 
ludzi, których ów problem nurtuje. Śmierć i miłość, uważa autor, to ulubiony temat poetów, pisarzy i mistyków. Z kolei A. Nowak stawia zaskakujące pytanie i odpowiada na nie słowami z Pieśni nad Pieśniami: „Czyżby miłość była wytłumaczeniem śmierci? [...] bo jak śmierć potężna jest miłość" (Pnp 8,6) ${ }^{65}$.

Antoni Nowak twierdzi, że sens, miłość, cierpienie i śmierć to pojęcia, które określają ludzki byt ${ }^{66}$. Dlatego uwzględniając wyjątkową godność ludzkiego bytu, który ma ograniczony czas fizycznej egzystencji, i biorąc pod uwagę relację między miłością a śmiercią, za moralny i zgodny z miłością należy uznać pogląd, według którego: „Kochać człowieka znaczy mówić mu: ty nie umrzesz" (G. Marcel) ${ }^{67}$. Stąd dla A. Nowaka miłujący człowiek, który jest obecny przy umierającym, umiłowanym człowieku, przeżywa śmierć w sposób specyficzny, nie umiera bowiem ktoś „,z zewnątrz”, lecz umiera ktoś „od wewnątrz”. Według A. Nowaka jest to jedyna relacja, która pozwala „doświadczyć" śmierci jako przebiegu psychicznego, a właściwie jako procesu duchowego. Nie trzeba nikomu udowadniać, że nikt nie przeżywa śmierci tak głęboko, jak miłujący człowiek, który jest obecny przy umieraniu ukochanej osoby. Może on powtórzyć za św. Augustynem: „I stałem się sam dla siebie wielkim problemem" 68 .

Relacja więc tych dwojga kochających się ludzi może okazać się niezwykle paradoksalna, umierający bowiem z kolei może własną śmierć zrozumieć jako dowód miłości wobec osoby ukochanej ${ }^{69}$.

Rozważania dotyczące problematyki miłości i śmierci oraz związanego z tym cierpienia A. Nowak streszcza w formie osobistej konkluzji, którą można odnieść do każdego człowieka: „Człowiek każdej kultury pragnie kochać i być kochanym. Jeżeli miłość i śmierć kształtują człowieka, dzieje się tak tylko wtedy gdy Ten, który jest Miłością - Jezus Chrystus, doświadczył absurdu śmierci i ją pokonał, może być odpowiedzią na pytanie dotyczące sensu życia i śmierci"70.

Odniesienie się w rozważaniach do kwestii przeżywania śmierci w atmosferze miłości, której źródłem jest Jezus Chrystus, dało możliwość spojrzenia

${ }^{65}$ Por. A. Nowak, Proces umierania $w$ aspekcie personalistycznej psychologii głębi, w: Cierpienie i śmierć, dz. cyt., s. 210.

${ }^{66}$ Por. A. Nowak, Proces umierania $w$ aspekcie personalistycznej psychologii glębi, dz. cyt., s. 210.

${ }^{67}$ Gabriel Honoré Marcel, ur. 7 grudnia 1889 roku w Paryżu, zm. 8 października 1973 roku w Paryżu. Filozof, dramaturg, krytyk literacki i muzyk francuski. Reprezentant chrześcijańskiego egzystencjalizmu, w: https://fr.wikipedia.org/wiki/Gabriel_Marcel, s. 1 [dostęp: 20.09.2016].

68 Augustyn, Wyznania IV, 4, thum. Z. Kubiak, Warszawa 1987, w: A. Nowak, Proces umierania $w$ aspekcie personalistycznej psychologii głębi, dz. cyt., s. 211.

${ }^{69}$ Por. A. Nowak, Proces umierania w aspekcie personalistycznej psychologii głębi, dz. cyt., s. 211.

${ }^{70}$ Por. tamże, s. 219, 229. 
na proces umierania jako na ars moriendi - „sztukę umierania”. W tym sensie uznano, że śmierć może być uważana za najpełniejszy akt oddania się Bogu i szczególny wyraz miłości ku Niemu ${ }^{71}$.

\subsection{Rola miłości w ,sztuce umierania”}

Prawo do przeżywania śmierci jako „sztuki umierania” daje wiara chrześcijańska, która pozwala na udział chrześcijanina w śmierci Chrystusa. Tak rozumiana ars moriendi jest spojrzeniem na udział w ,sztuce” umierania Jezusa Chrystusa. Nie tylko chrześcijanin, ale i każdy w ogóle człowiek może połączyć własne cierpienia, umieranie i śmierć ze śmiercią Jezusa Chrystusa, by przez swą miłość stać się niejako współodkupicielem, podobnie jak rozumiał to Apostoł Narodów, pisząc: „Teraz raduję się w cierpieniach za was i ze swej strony w moim ciele dopełniam braki udręk Chrystusa dla dobra Jego Ciała, którym jest Kościół" (Kol 1,24).

W związku z tym Jerzy Misiurek uważa, że to dzięki łączności w duchu miłości ze śmiercią Chrystusa ponadludzkiej wartości nabierają choroba i śmierć, stając się siłą zbawczą tak dla cierpiącego człowieka, jak i dla świa$\mathrm{ta}^{72}$. Jednak J. Misiurek, powołując się na Stanisława Olejnika, twierdzi, że zarówno etos umierania, jak i w ogóle ars moriendi, można utożsamić z ars vivendi, $\mathrm{z}$ etosem życia wraz ze wszystkimi jego implikacjami, zarówno negatywnymi, związanymi z unikaniem grzechów, zwłaszcza śmiertelnych, jak i pozytywnymi związanymi z nabywaniem i rozwijaniem cnót, głównie zaś miłości, stanowiącej samą istotę chrześcijaństwa ${ }^{73}$.

Aby lepiej zilustrować problematykę sztuki umierania w kontekście miłości, w ramach refleksji teologicznej podano kilka przykładów ludzi, którzy doświadczyli ars moriendi. Do nich należy Juliusz Słowacki, o którego ostatnich chwilach życia pisał późniejszy abp Zygmunt Szczęsny: „Obudziła się w nim głęboka wiara i zatarła ostatnie ślady wpływu Towiańskiego. Wielokroć powtarzał przed śmiercią: Najwyższą ziemską miłością kochałem moją matkę, czymże jednak jest to ukochanie wobec miłości Chrystusa"74.

W związku z tym J. Misiurek uważa, że człowiek, który umiera godnie, z nadzieją osiągnięcia życia wiecznego, uczy tym samym innych odpowied-

${ }^{71}$ Por. H. Volk, Das chrisliche Verstandnis des Todes, Münster 1957, s. 76, w: Towarzystwo Naukowe Katolickiego Uniwersytetu Lubelskiego, https://books.google.sk, s. 1 [dostęp: 26.06.2017], cyt. w: J. Misiurek, „Ars moriendi” - „sztuka umierania”, w: Cierpienie i śmierć, dz. cyt., s. 235.

72 Por. J. Misiurek, Ars moriendi" - „sztuka umierania, dz. cyt., s. 239.

73 Za S. Olejnik, Etos umierania, „Ateneum Kapłańskie”, 72(1980), t. 95, s. 66, w: J. Misiurek, Ars moriendi" - ,sztuka umierania, dz. cyt., s. 239.

74 Por. J. Makłowicz, Religijność Juliusza Stowackiego, Lwów 1909, s. 22 i n., w: J. Misiurek, Ars moriendi" - ,sztuka umierania, dz. cyt., s. 242. 
niej postawy wobec śmierci, uczy ich także sztuki umierania, składając im przy tym ostatni dar miłości ${ }^{75}$.

Innym przykładem praktycznej miłości, która w sensie transcendentnym wpływa na przeżywanie cierpienia, jest postawa pewnego człowieka, z którym spotkała się Krystyna Sajdok. Nawiązanie znajomości z tą osobą, która w tym czasie poruszała się już na wózku inwalidzkim, przeżywając głębokie cierpienie, pozwoliło K. Sajdok na usłyszenie wiarygodnego świadectwa wiary: „Wierzę gorąco i to pozwoliło mi przetrwać najgorszy okres choroby i całkowitego bezwładu. Mam dziewczynę, która mnie kocha, i właśnie jej uczucie zmobilizowało mnie do pracy nad sobą. Obecnie jeżdżę już na wózku inwalidzkim i chyba nie będzie już inaczej. Ale nie przeraża mnie ten stan - Bóg wie, co robi" $"$.

\subsection{Wpływ milości na cierpienie w socjologicznym sensie}

Teologiczne rozważania na temat wpływu miłości na przeżywanie cierpienia i śmierci dopełnia refleksja Anny Barcik, która zagadnienia samotności i cierpienia ujmuje w aspekcie socjologicznym. Punktem wyjścia dla A. Barcik jest Pismo Święte Starego Testamentu. Na podstawie tekstu o stworzeniu kobiety $(\operatorname{Rdz} 1,31)$ autorka dochodzi do wniosku, że największym pragnieniem każdego człowieka jest dążenie do przynależności społecznej i miłości oraz do zakorzenienia i kochania. Tę odwieczną prawdę w doskonały sposób, zdaniem autorki, rozwinął w swych dialogach Michel Quist. Według niego źródłem szczęścia ludzkości jest miłość, a człowiek wyrzucający to uczucie ze swego życia przeżywa pustkę i nieobecność czegoś, brakuje mu jakiegoś światła. Powiada więc pisarz: „Jeżeli chcesz żyć, nie zatrzymuj swojego życia dla siebie". Autor wskazuje, że pełnię człowieczeństwa i zjednoczenia ze wspólnotą osiąga się poprzez miłość Boga i ludzi ${ }^{77}$.

W refleksji dotyczącej przeżywania samotności A. Barcik przypomina, co na temat samotności, ale kontemplacyjnej, mówi T. Merton. Według tego mistyka trzeba doświadczyć wielu chwil słabości, pokonać wiele trudności w walce z samym sobą, aby odnaleźć prawdziwą i radosną samotność kontemplacyjną, czyli prawdziwą miłość Bożą. Stąd też prawdziwa samotność

75 J. Misiurek, Ars moriendi” - „sztuka umierania, dz. cyt., s. 244.

76 Wcześniej ta sama chora osoba pyta: „Czy w mojej niesprawności mogę się doszukać miłości Boga do mnie?” K. Sajdok, „Transcendentny wymiar cierpienia”, w: Cierpienie i śmierć, dz. cyt., s. 254-255.

77 Por. M. Quist Rozmowy o miłości, tłum. M. Rzepniewski, Warszawa 1989, s. 19, w: A. Barcik, Samotność i cierpienie w aspekcie socjologicznym, w: Cierpienie i śmierć, dz. cyt., s. 261. 
w życiu ludzkim znajduje swe źródło w pokorze, w miłości, w pokoju i w milczeniu $^{78}$.

Jednym z największych i najbardziej istotnych pragnień człowieka jest pęd do życia. W związku z tym stara się on zdobywać wykształcenie, sławę, pieniądze. Dlatego też nieustannie poszukuje możliwości spełnienia się, a realizacja zamierzonych celów przynosi jemu radość. Jednakże wcześniej czy później zaczyna doświadczać cierpienia. Dostrzegamy to zarówno w naszym własnym życiu, jak i w otaczającym nas świecie. „Cierpienie jest rzeczywistością o tysiącu twarzy"79. Jest wpisane w wymiar człowieczeństwa i ludzkiej doczesnej egzystencji. Pojawia się w różnym czasie i nie zależy od wieku człowieka. Przychodzi często wtedy, kiedy jest najmniej spodziewane. Dotyczy więc każdego i nikt się przed nim nie schowa. Współczesnemu światu trudno jest je zrozumieć i przyjąć. Najczęstszą reakcją na cierpienie jest bunt. Niejednokrotnie staje się ono argumentem za tym, że nie ma Boga, bo gdyby istniał, nie pozwoliłby, aby cierpiało tyle osób. Dlatego człowiek dąży do przezwyciężenia cierpienia i próbuje zrozumieć jego sens. W tym celu cierpienie rozpatrywano $\mathrm{z}$ różnych punktów widzenia.

Człowiek próbuje je przezwyciężać dzięki coraz doskonalszym lekom i coraz lepszemu medycznemu sprzętowi. Jednakże problem przezwyciężenia cierpienia nie dotyczy wyłącznie fizycznej konstrukcji człowieka. Człowiek bowiem jest bytem cielesno-duchowym. Wobec tego podczas prób przezwyciężania cierpienia nie można zapomnieć o duchowym elemencie ludzkiej egzystencji. W związku z tym niezastąpiony okazuje się Kościół i teologia, która kieruje uwagę człowieka na wiarę. Teologia, inaczej niż medycyna, stara się dać odpowiedź na pytanie: Jakie są przyczyny cierpienia?, a głównie próbuje dać odpowiedź na pytanie: Czy i jaki jest sens cierpienia? Taką odpowiedź zaproponował św. Jan Paweł II w liście apostolskim Salvifici doloris z roku 1984. Poszukując odpowiedzi na pytanie dotyczące sensu cierpienia, teologia, dzięki wierze w istnienie Boga, nie tylko próbuje przybliżyć ludziom tajemnicę ludzkiego cierpienia, ale proponuje też środki, które skutecznie pomagają w przeżywaniu i przezwyciężaniu tego doświadczenia.

Dzięki teologii, dla której źródłem jest objawienie, możliwe stało się danie przynajmniej częściowej odpowiedzi na pytanie: Dlaczego cierpienie? Człowiek zadaje je nie tylko innemu człowiekowi, światu, ale także Bogu.

${ }^{78}$ Por. T. Merton Posiew kontemplacji, thum. M. Morstin-Górska, Kraków 1989, s. 91; T. Merton Ewolucja pojęcia czystości, cyt. za: A. Barcik, Samotność i cierpienie w aspekcie socjologicznym, dz. cyt. Por. T. Merton, Nikt nie jest samotna wyspa, Kraków 2006, w: A. Barcik, Samotność i cierpienie w aspekcie socjologicznym, dz. cyt., s. 268-269.

79 Jan Paweł II, Przemówienie w Lourd 1983, www.martyria.diecezja.elk.pl/lu_14, s. 1 [dostęp: 27.06.2017]. Por. też Jan Paweł II, Salvifici dolores, nr 5, w: http://www.opoka.org.pl/biblioteka/W/ WP/jan_pawel_ii/listy/salvifici_dolorors, s. 2 [dostęp: 27.06.2017]. 
Odpowiedź na nie musi uwzględniać tajemnicę zbawczego sensu cierpienia związanego z odkupieniem człowieka przez Jezusa Chrystusa dzięki cierpieniu ofiarowanemu na Krzyżu i podjętemu z nieskończonej miłości do każdego człowieka. W tym sensie Jezusowe cierpienie stało się najwyższym darem miłości ${ }^{80}$. W tym kontekście ma sens postawienie sobie pytania: Czy na pojawiające się w ludzkim życiu cierpienie, które według Pisma Świętego jest złem (por. Księga Hioba), nie należy spoglądać jak na zaproszenie i powołanie do przyjęcia zbawiającego cierpienia z miłości do Boga i bliźniego, w czym miałaby pomóc wiara $\mathrm{w}$ asystencję Boga? Odpowiedź na to pytanie daje nam jeden z największych teologów czasów apostolskich - św. Paweł. W Liście do Kolosan pisze on następujące słowa: „Teraz raduję się w cierpieniach za was i ze swej strony dopełniam braki udręk Chrystusa dla dobra Jego Ciała, którym jest Kościół" (Kol 1,24). Jest to więc zaproszenie do przeżywania Ewangelii cierpienia ${ }^{81}$.

Pozytywna odpowiedź na propozycję Boga, to znaczy przyjęte z wiarą i nadzieją choroba i cierpienie, mogą stać się miejscem świętym, ponieważ są terenem spotkania i zjednoczenia człowieka z Bogiem, co znajduje potwierdzenie w życiu wielkiej liczby ludzi świętych. W tym miejscu można przypomnieć takie osoby, jak: św. Jana od Krzyża (1542-1591), św. Małgorzatę Marię Alacoque (1647-1690), bł. Annę Katarzynę Emmerich (1774-1824), św. Teresę od Dzieciątka Jezus (1873-1897), bł. Anielę Salawę (1881-1922), bł. Marcelinę Darowską (1827-1917), św. Ojca Pio (1887-1968) czy św. Faustynę Kowalską (1905-1938). Podobnie do nich, każdy człowiek może postrzegać chorobę jako nawiedzenie, działanie opatrzności Bożej, doświadczenie i przyczynę opamiętania, naśladowania Chrystusa, czas łaski, miłość Zbawiciela i krzyża. Chrześcijanin, który z wiarą przyjmuje cierpienie, ma świadomość, że Chrystus identyfikuje się z nim w wyjątkowy sposób. W tak rozumianym powołaniu do przeżywania i przezwyciężania trudnych doświadczeń na cierpienie można spoglądać jak na próbę człowieka, a następnie przeżywać je jako jeden z najbardziej korzystnych sposobów apostolatu. Miałaby w tym pomóc świadomość przeżywania cierpienia jako pewnego rodzaju modlitwy oraz proponowane przez Kościół sakramenty, zwłaszcza Eucharystii i namaszczenia chorych. Oprócz nadprzyrodzonych środków, jakimi są sakramenty, Kościół i reprezentanci różnych dyscyplin naukowych interesujących się życiem duchowym człowieka, takich jak: teologia, chrześcijańska filozofia, psychologia, chrześcijańska antropologia, bardzo silnie podkreślili niezastąpioną rolę miłości będącej jednym z najlepszych środków pomagających w przeżywa-

${ }^{80}$ Por. Jan Paweł II, Salvifici dolores, nr. 9-15, w: http://www.opoka.org.pl/biblioteka/W/WP/ jan_pawel_ii/listy/salvifici_dolorors, s. 3, 4, 5 [dostęp: 27.06.2017].

${ }^{81}$ Por. tamże, nr 25, s. 10. 
niu cierpienia i śmierci. W tym kontekście wyrażony był pogląd, że cierpienie jest po to, żeby wyzwalało miłość, a dokładniej mówiąc, aby było źródłem takiej miłości, która będzie siłą potrzebną do służby i realizacji słów Jezusa Chrystusa dotyczących sądu ostatecznego, w czasie którego ludzkie życie będzie oceniane z uwagi na sposób realizacji miłości bliźniego: „Byłem chory, a odwiedziliście Mnie" (Mt 25,36). Wobec tego można przyjąć, że cierpienie potrzebne jest nie tylko chorym, ale i wszystkim zdrowym osobom. Tym, którzy w jakikolwiek sposób towarzyszą chorym, cierpienie ma przypominać o końcu ziemskiej egzystencji oraz o zbliżającym się momencie ostatecznego odejścia z tego świata. Jest to więc sposób przygotowania się osoby zdrowej na przyjęcie cierpienia i na osobistą śmierć.

Jakkolwiek na temat cierpienia powiedziano stosunkowo wiele, pozostanie ono w swojej istocie niezgłębioną tajemnicą. Daje się ją częściowo wyjaśnić w połączeniu z tajemnicą miłości, której źródłem jest Bóg. Podjęcie refleksji na ten temat potwierdziło prawdę o tym, że łatwiej doświadczać cierpienia i śmierci w poczuciu, że jest się kochanym. Równocześnie przybliżenie tajemnicy o zbawieniu dzięki przeżyciu ,pełni cierpienia” przez Jezusa Chrystusa, podjętego z nieskończonej miłości do każdego człowieka, pozwala uświadomić sobie w perspektywie wieczności sens zjednoczenia swojego cierpienia z cierpieniem Jezusa Chrystusa. W ten sposób potwierdzona została prawda o niezastąpionej roli miłości w twórczym przeżywaniu cierpienia i śmierci.

\section{ROLE OF LOVE IN LIVING SUFFERING AND DEATH}

\section{Summary}

The article analyzes the importance of love on living suffering and death. This problem was considered in few perspectives.

First of all, based on the natural law, natural need of love as well as ability to withstand suffering was emphasized was considered. The religious point of view was noted making use of the teachings of the Church Fathers. Paul's Apostle point of view is corresponding with this these. In his opinion the love is the source of power which is necessary to living suffering and death. Contemplating the psychological viewpoint examination of people characterized by strong personality has become instrumental. These people long for overcoming their extreme situation of suffering and death.

The problem of euthanasia and the role of the sacrament of the Anointing of the Sick was considerated too. Mistical aspect of the influence of love on living suffering and death is the further perspective that was important in this relfection. On the other hand the situation of a sick man, who forms community of love in the Church community which contemplates love, was anlized in eschatological aspect. Yet further 
aspects: philosophical and anthropological, in relation to the subject of influence of love on suffering and death, combine in the following question: Is death the meaning of life? Finally, theologians have considered the influence of love on living suffering and death in the psychological, ethical, transcendental and sociological sense.

Lastly, sociological aspect was not missing in contemplating the influence of love on living suffering and death. This problem was examined in the context of people who suffer and at the same time live in solitude.

Apart from that, it is the feeling that someone is somewhere rooted and loved. In the context of living suffering and death, realization of fullness of humanity and unification with community was emphasized which is achievable through love to God and neighbour - particularly love to a suffering person.

Słowa kluczowe: cierpienie; miłość; życie; śmierć; zbawienie; tajemnica; Bóg

Keywords: suffering; love; life; death; salvation; mystery; God

\section{BIBLIOGRAFIA}

Wszystkie cytowane w niniejszym artykule źródła dotyczące konferencji M. Darowskiej znajdują się w Archiwum Zgromadzenia Niepokalanego Poczęcia NMP w Szymanowie. Przytaczane tu tomy oznaczają tzw. tomy rzymskie, przygotowane do procesu beatyfikacyjnego m. M. Darowskiej, a zawierające źródła przepisane z autografów.

Augustyn, Wyznania IV, 4, thum. Z. Kubiak, Warszawa 1987.

Barcik A., Samotność i cierpienie w aspekcie socjologicznym, w: Cierpienie i śmierć, red. J. Nowak, Homo Meditans, t. XIII, Lublin 1992, s. 259-273.

Chmielewski M., Cierpienia biernej nocy zmysłów $i$ ducha $w$ doświadczeniu mistycznym Cecylii Dziatyńskiej, w: Cierpienie i śmierć, red. J.A. Nowak, Homo Meditans, t. XIII, Lublin 1992, s. $115-130$.

Darowska M., Konferencje, seria 1, Konferencja 14, 26 XII 1869 r., t. 42, s. 19.

Darowska M., Konferencje, seria 2, konferencja 32: O wspótcierpieniu z Panem Jezusem - Wielki Post 1882 r.

Darowska M., Konferencje, seria 3, konferencja 7: O umartwieniu i skupieniu wielkopostnym, 9 III 1884 r., t. 42, s. 143-144.

Darowska M., Konferencje, seria 4, konferencja 6: Stowo wielkopostne - Popielec 1889 r.

Darowska M., Konferencje, seria 7, konferencja 10: O umartwieniu, 1 XI 1901 r.

Darowska M., Konferencje, seria 7, konferencja 12: O Wielkim Poście, 16 II 1902.

Darowska M., Konferencje, seria 7, konferencja 45: O poście, 9 II 1910 r.

Darowska M., Konferencje, seria 7, konferencja 46, 13 V 1910 r.

Darowska M., List do matky Józefy Karskiej z 27 VIII 1855 r. (P.4.1.II.15), t. 10, s. 59.

Darowska M., List do matky Józefy Karskiej z 27 I 1856 r. (P. 4.1III.20), t. 10, s. 85-86.

Darowska M., Rekolekcje dla sióstr, 30 VII-3 VIII 1879 r., t. 39, s. 33, 48-49, 69.

Darowska M., Rekolekcje dla wychowanek, czerwiec 1880 r., nauka 4: O cierpieniu i niebezpieczeństwach życia, t. 46.

Darowska M., Rekolekcje na uroczystości zakonne 1881 r., t. 40, s. 78.

Darowska M., Rekolekcje na uroczystości zakonne przed Wniebowzięciem 1881 r., t. 40, s. 77.

Darowska M., Rekolekcje o mitości, 13-18 XI 1877 r., t. 38, s. 139, 142-143. 
Darowska M., Rekolekcje o Najświętszej Maryi Pannie 1886 r., t. 41, s. 84, 147.

Darowska M., Rekolekcje o ufności z 1882 r., nauka 3.

Darowska M., Rekolekcje o ufności z 1822 r., nauka 6.

Darowska M., Rekolekcje przed kapitula 1909 r., nauka 1 (P.19.2.II.3), t. 5, s. 117.

Darowska M., Rekolekcje przed kapituła 1909 r. nauka 1, t. 5, s. 121-122.

Darowska M., Rekolekcje przed Zielonymi Świętami 1876 r., t. 40, s. 130.

Darowska M., Rekolekcje wielkopostne 1880 r., t. 39, s. 126-128.

Dehon L., Zalecenia i rady Ojca Dehona dla swoich zakonników, w: Dyrektorium duchowe Księży Najświętszego Serca Jezusowego, Warszawa 1997, s. 248-370.

Dehon L., O życiu mitości do Najświętszego Serca Jezusowego, (De la vie d'amour envers le Sacré-Coeur), thum. W. Łukasik, Stopnica 2002.

Drączkowski F., Cierpienie i śmierć w nauce Ojców Kościoła, w: Cierpienie i śmierć, red. J. Nowak, Homo Meditans, t. XIII, Lublin 1992, s. 29-48.

Filogeneza, https://pl.wikipedia.org/wiki/Filogeneza, s. 1 [dostęp: 20.09.2016].

Gabriel Marcel, https://fr.wikipedia.org/wiki/Gabriel_Marcel, s. 1 [dostęp: 20.09.2016].

Gaweł J., Ostatni zeszyt „Zapisków codziennych” o. Dehona z 1925, „Informator SCJ” z dnia 23.02.1976, s. 62-69.

Haring B., Heilender Dienst. Ethische Probleme der modernen Medzin, Mainz 1972.

Jan od Krzyża, Noc ciemna, 2, 11, 1-7, w: Dzieła, tłum. B. Smyrak, Kraków 1986, s. 412-488.

Jan od Krzyża, Pieśń duchowa, w: Dzieła, tłum. B. Smyrak, Kraków 1986, s. 554-625.

Jan od Krzyża, Żywy płomień miłości, w: Dzieła, tłum. B. Smyrak, Kraków 1986, s. 744-767.

Jan Paweł II, Cierpienie stawia was w sercu Tajemnicy Odkupienia (Homilia 5.06.1983), „L'Osservatore Romano" 4(1983), nr 5-6.

Jan Paweł II, „Cierpienie świadome, przyjęte z wiarą” [...] Do chorych (15.08.1983), „L'Osservatore Romano" 4(1983), nr. 7-8, s. 11.

Jan Paweł II, Encyklika Dives in misericordia, Wrocław 1980.

Jan Paweł II, Encyklika Redemptor hominis, Wrocław 1986.

Jan Paweł II, Krzyż Chrystusa - fundamentem nadziei. Audiencja generalna (31.03.1983), „L'Osservatore Romano" 4 (1983), nr 3, s. 18.

Jan Paweł II, List apostolski Salvifici doloris, Wrocław 1984.

Jan Paweł II, List apostolski Salvifici doloris, http://www.opoka.org.pl/biblioteka/W/WP/jan_pawel_ii/listy/salvifici_doloris [dostęp: 14.09.2016].

Jan Paweł II, Przemówienie w Lourdes 1983, w: www.martyria.diecezja.elk.p1/lu_14, s. 1 [dostęp: 27.06.2017].

Jan Paweł II, Także i wy nas obdarzacie. Spotkanie z chorymi, starszymi, ułomnymi (11.09. 1983, Wiedeń), „L'Osservatore Romano” 9(1983), s. 10.

Jan Paweł II, W cierpieniu spotykamy się z tajemnica śmierci i zmartwychwstania Chrystusa, s. 4, w: Jan Paweł II, Cierpienie stawia nas w sercu Tajemnicy Odkupienia (Homilia 5.06.1983), „L'Osservatore Romano” 4(1983), nr. 5-6, s. 32.

Katechizmus Katolíckej Cirkvi, Trnava 1999.

Klemens Alexandrijský, Stromaty, VI 71,4, thum. J. Pliszczyńska: w: Dywany, I-VIII, Lublin 1972 (mps).

Kódex Kánonického Práva, Bratislava 1996.

Kongregacja Nauki Wiary, Deklaracja o eutanazji Iura et bona, rozdz. II, nr 1, http://www.opoka. org.pl/biblioteka/W/WR/kongregacje/kdwiary/zbiór., 2 [dostęp: 21.09.2016].

Konstytucje SCJ, Kraków 1983.

Krakowiak C., Sens cierpienia i śmierci w świetle liturgii sakramentu namaszczenia chorych $i$ wiatyku, w: Cierpienie i śmierć, red. A. Nowak, Homo Meditans, t. XIII, Lublin 1992, s. 85- 97.

Krąpiec M., Czy śmierć jest sensem życia, w: Cierpienie i śmierć, red. A. Nowak, Homo Meditans, t. XIII, Lublin 1992, s. 149-161.

Makłowicz J., Religijność Juliusza Słowackiego, Lwów 1909. 
Marcelina Darowska, https://pl.wikipedia.org/wiki/Marcelina_Darowska, s. 1 [dostęp: 15.09.2016].

Merton Th., Nikt nie jest samotna wyspa, thum. M. Morstin-Górska, Kraków 2006.

Merton Th., Posiew kontemplacji, tłum. M. Morstin-Górska, Kraków 1989.

Misiurek J., Ars moriendi” - „sztuka umierania, w: Cierpienie i śmierć, red. A. Nowak, Homo Meditans, t. XIII, Lublin 1992, s. 231-244.

Nowak A., Do czytelnika, w: Cierpienie i śmierć, red. A. Nowak, Homo Meditans, t. XIII, Lublin 1992, s. 7-11.

Nowak A., Proces umierania w aspekcie personalistycznej psychologii głębi, w: Cierpienie i śmierć, red. A. Nowak, Homo Meditans, t. XIII, Lublin 1992, s. 209-229.

Olejnik S., Etos umierania, „Ateneum Kapłańskie” 72(1980), t. 95, s. 62-77.

Ontogeza, https://pl.wikipedia.org/wiki/Ontogeneza, s. 1 [dostęp: 20.09.2016].

Paweł VI, Adhortacja apostolska Cum proximus (14.09. 1963), ,Acta Apostolicae Sedis”, 55(1963), s.729-733.

Pieper J., Śmierć i nieśmiertelność, tłum. A. Morawska, Znaki Czasu t. 15, Paris 1970.

Poleszak L., Serce Jezusa. Kult Najświętszego Serca Jezusowego w Zgromadzeniu Księży Najświętszego Serca Jezusowego (1878-2009), Kraków 2010.

Rosik S., Tajemnica ludzkiego cierpienia a moc Chrystusowego krzyża, w: Cierpienie i śmierć, red. A. Nowak, Homo Meditans t. XIII, Lublin 1992, s. 61-83.

Quoist M., Rozmowy o miłości, tłum. M. Rzepniewski, Warszawa 1989.

Sajdok K., Transcendentny wymiar cierpienia, w: Cierpienie i śmierć, red. A. Nowak, Homo Meditans t. XIII, Lublin 1992, s. 245-257.

Seuden S., „Problem cierpienia u chorych na schizofrenię”, w: Cierpienie i śmierć, red. A. Nowak, Homo Meditans t. XIII, Lublin 1992, s. 193-207.

Sobański R., Człowiek - podmiot praw i obowiązków we wspólnocie Kościoła, w: L. Balcer, Człowiek we wspólnocie Kościoła, Warszawa 1971, s. 66-86.

Sobór Watykański II, Dekret o apostolstwie świeckich Apostolicam actuositatem, w: Sobór Watykański II, Konstytucje, dekrety, deklaracje, Poznań 1968, s. 377-401.

Sobór Watykański II, Konstytucja dogmatyczna o Kościele Lumen gentium, w: Sobór Watykański II, Konstytucje, dekrety, deklaracje, Poznań 1968, s. 104-166.

Sobór Watykański II, Konstytucja Duszpasterska o Kościele w świecie współczesnym Gaudium et spes, w: Sobór Watykański II, Konstytucje, dekrety, deklaracje, Poznań 1986, s. 526-606.

Sujak E., Rozważania o ludzkim rozwoju, Kraków 1975.

Merton T., Ewolucja pojęcia czystości, w: T. Merton, Posiew kontemplacji. Moja wizja świata i inne pisma, Pisma, t. III, tłum. M. Tazbir, Warszawa 1987, s. 91-99.

Urbański S., «Zjednoczenie z Bogiem w próbie cierpienia i „śmierci sobie“» wedlug nauki Marceliny Darowskiej, w: Cierpienie i śmierć, red. A. Nowak, Homo Meditans, t. XIII, Lublin 1992, s. 99-113.

Vassena A., "Prymat ofiarowania się z miłości w charyzmacie o. Dehona na podstawie pierwszych dwóch zeszytów „Dziennika” (Notes Quotidiennes), „Dehoniana” (wyd. polskie) 3(1979), s. 229-242.

Volk H., Das chrisliche Verstandnis des Todes, Münster 1957, s. 76, w: Towarzystwo Naukowe Katolickiego Uniwersytetu Lubelskiego: https://books.google.sk, s. 1 [dostęp: 26.06.2017], cyt. w: J. Misiurek, „Ars moriendi” - „sztuka umierania w: Cierpienie i śmierć, red. A. Nowak, Homo Meditans, t. XIII, Lublin 1992, s. 235.

Zubert W., Prawa chorego we wspólnocie Kościoła, w: Cierpienie i śmierć, red. A. Nowak, Homo Meditans, t. XIII, Lublin 1992, s. 131-148.

JERZY BERNACIAK SCJ - ks. dr. W 1997 roku, obronił pracę doktorską na Wydziale Teologii KUL. Tytuł pracy: Geneza i specyfika duchowości miłości i wy- 
nagrodzenia $w$ świetle pism Ojca Jana Leona Dehona, Założyciela Księży Najświętszego Serca Jezusowego. Od 1997 roku pracuje na Słowacji. Prowadząc działalność duszpasterską, pogłębia wiedzę teologiczną,również z zakresu katolickiej nauki społecznej. Owocem prowadzenia studium są arytkuły o tematyce teologicznej oraz związane ze społeczną nauką Kościoła. 